\title{
Cultivar and Maturity Effects on the Quality Attributes and Ethanol Potential of Sweet Sorghum
}

\author{
Marsha R. Cole ${ }^{* 1}$, Gillian Eggleston ${ }^{1}$, Eric Petrie ${ }^{2}$, Sophie M. Uchimiya ${ }^{1}$, and Caleb Dalley ${ }^{3}$ \\ ${ }^{1}$ Southern Regional Research Center, Agricultural Research Services, U.S. Department of \\ Agriculture, New Orleans, LA, 70124 \\ ${ }^{2}$ Sugarcane Research Unit, Agricultural Research Services, U.S. Department of Agriculture, \\ Houma, LA, 70360 \\ ${ }^{3}$ Weed Science, Hettinger Research Extension Center, North Dakota State University, Hettinger, \\ ND, 58639
}

\begin{abstract}
Sweet sorghum is a promising feedstock crop for the manufacture of biofuels and bioproducts. Its large starch content may be an opportune source of untapped fermentable sugars to add economical value to sweet sorghum juices and processing by-products. In this study, four commercial cultivars, Dale, M81E, Theis, and Top 76-6 were grown in Louisiana (over 2 years) and studied at the milk (Mi), soft dough (SD), hard dough (HD), physiological (PM), and postphysiological (PPM) maturity stages to determine the value of sweet sorghum starch and the optimal cultivar, maturity, and environment ideal for processing and fermentation juice quality. Juice quality and physical crop attributes essential to processing and fermentation were strongly influenced by environmental and cultivar interactions $(\mathrm{P}<0.0001)$; however, total sugars were specifically affected by cultivar and maturity interactions. Although a moderately-strong correlation between total sugars and juice Brix was found $(\mathrm{R}=0.767, \mathrm{P}<0.0001, \mathrm{n}=151)$, the use of Brix as an in-field harvesting indicator to predict stalk maturity is not recommended since it does not consider cultivar influences. Total sugars and total starch in extracted juice were greatest at HD maturity in Top 76-6 and M81E, respectively. Added-value ( 6-17\%) can be theoretically obtained from starch if fermented in sweet sorghum juices, and possibly more when including other starch-rich processing by-products and seed-heads that can be recycled back into fermentations. Top 76-6 was the best cultivar for syrup manufacturing; Dale and M81E were most attractive for fermentations only if their high starch content are economically incorporated into the manufacturing and fermentation processes.
\end{abstract}

Keywords: cultivars; maturity; quality attributes; starch; ethanol yields; processing characteristics.

\section{Abbreviations}

Mi Milk physiological maturity stage

SD Soft dough physiological maturity stage

HD Hard dough physiological maturity stage

PM Physiological maturity stage

PPM Post-physiological maturity stage 
Brix Per cent dissolved refractometric solids

TN/TOC Total oxidizable and non-oxidizable organic nitrogen/carbon

YAN Yeast assimilable nitrogen

EtOH Ethanol

G Genotype/Cultivar interaction

M Maturity interaction

E Environmental interaction

ICUMSA International Commission for Uniform Methods of Sugar Analysis

NTU Nephelometer turbidity units

HPAEC-IPAD High performance anion exchange chromatography with integrated pulsed amperometric detection

\section{Introduction}

Biochemicals produced from renewable plant biomass like sweet sorghum (Sorghum bicolor L. Moench) are an attractive alternative to scarce fossil fuel stores. Sweet sorghum is a high biomass and sugar yielding crop. It is a widely adopted crop that is easily cultivated from seed, requires low input, has a wide geographic suitability that allows for substantial breeding potential, and has potential for plantings each cropping season in the southeast U.S. (Tew et al., 2008).

Although sweet sorghum has been traditionally used for forage or small-scale syrup production, several private-sector U.S. and international consortiums are now developing a largescale industry to supply both the food-grade syrup market and the anticipated bioprocessing demand (Eggleston et al., 2015a). While most of these groups are still in the planning stages, a new large-scale processing plant in Sikeston, Missouri, i.e., Heckemeyer Mill, has started the large-scale production of food and industrial-grade syrup as well as potable alcohol, and in the immediate future, various biochemical and bioproducts (Eggleston et al., 2015a). Heckemeyer Mill is currently capable of crushing up to $\sim 45$ ton per day and producing at least 8,000 gal of juice (Eggleston et al., 2015a). There have also been some reports indicating the potential to incorporate sweet sorghum into existing sugarcane factories, specifically during the crop offseason, with sweet sorghum being cultivated on fallowed sugarcane beds before the season starts (Kim \& Day, 2011; Linton et al., 2011; Ricaud, 1970; Tew et al., 2008).

One processing obstacle encountered at Heckemeyer Mill, was the high concentration of starch, particularly insoluble starch, in sweet sorghum juice, which was attributable to forage harvesting and/or type of cultivar. Insoluble starch is a natural juice impurity constructed of entangled, soluble glucopolymers, which makes this physical starch form very difficult to solubilize (Chen \& Chou, 1993). A high amount of starch is known to complicate downstream syrup processing because the formation of swollen granules can increase syrup viscosity. Furthermore, insoluble starch can readily settle on the evaporator coils and burn, yielding an unsellable syrup product (Eggleston et al., 2015a). Removing the seed-heads, which contain larger granules of starch, prior to juice extraction, can markedly reduce insoluble starch 
concentrations downstream and in the final syrup product. Extracted sweet sorghum juice, however, still contains large quantities of starch, but they are much smaller than those found in the primary and auxiliary seed-heads (Eggleston et al., 2015b). Fortunately, twice sedimentation and clarification can remove most of the small and large insoluble starch granules allowing for the production of acceptable food-grade or non-food-grade, commercial syrup (Eggleston et al., 2015a). This results in processing by-products, i.e., sediment, clarification mud, seed-heads, and bagasse, rich in soluble and insoluble starch, which have potential to supplement fermentation as a source of untapped fermentable sugars (Eggleston et al., 2015a).

Most sweet sorghum research has focused mainly on crop production characteristics and, to a limited extent, process optimization (Andrzejewski et al., 2013b; Eggleston et al., 2015a) with very little on quality attributes. Thus, more research is needed to underpin the cultivar, maturity, and environmental effects that impact juice quality, e.g., starch quantity and quality, and its potential to augment fermentation yields, harvesting, processing, and end-products for this commercial industry (Andrzejewski et al., 2013a, 2013b; Eggleston et al., 2015a, 2015b). The objectives of this study, therefore, were (i) to characterize the agronomic, biomass, and juice quality traits of four commercial sweet sorghum cultivars (ii) at five crop maturities over 2 years, and (iii) to evaluate the fermentable potential of sweet sorghum juice sugars with and without untapped sugars from hydrolyzed starch.

\section{Experimental}

All chemicals and standards were analytical grade and purchased from Sigma Aldrich Company (St. Louis, MO).

\subsection{Weather Data}

Temperature and rainfall were taken from the USDA Sugarcane Research Unit, Houma, LA weather station (KLAHOUMA8) for the 2013 and 2014 study. Average monthly temperatures and rainfall are shown in Fig. 1.

\subsection{Sampling Methods and Juice Extraction for Maturity and Cultivar Study in Schriever, LA}

Field studies were conducted in 2013 and 2014 at the USDA-ARS Sugar Research Laboratory's Ardoyne Research Farm (Schriever, LA). The sweet sorghum evaluated included four "mid to late-maturing" inbred sweet sorghum cultivars (Dale, M81E, Theis, and Top 76-6 or Topper) (Broadhead et al., 1970, 1974, 1981; Day et al., 1995). The 2013 study was planted in a randomized complete block design on May 9, 2013 on Schriever clay in twin rows on top of a conventional $1.8 \mathrm{~m}$ wide, single raised beds measuring $107 \mathrm{~m}$ long as established for fallow sugarcane-sweet sorghum field conversion, with four replicates. The 2014 study was planted on April 24, 2014 on Cancienne silt loam soil using the same plot design and the same location. Each main plot was planted at a density of approximately 140,000 plants/ha. Following planting, metolachlor plus atrazine at 1.42 plus $1.2 \mathrm{~kg} / \mathrm{ha}$ was applied to all plots. Upon reaching the four leaf growth stage, pendimethalin $(1.6 \mathrm{~kg} / \mathrm{ha})$ was added to provide additional pre-emergence control of grass and broadleaf weeds. Prior to planting, plots were fertilized using liquid fertilizer injected on both sides of the bed at a rate of $90 \mathrm{~kg} / \mathrm{ha} \mathrm{N}, 22 \mathrm{~kg} / \mathrm{ha} \mathrm{K}_{2} \mathrm{O}$, and $45 \mathrm{~kg} / \mathrm{ha} \mathrm{P}_{2} \mathrm{O}_{5}$ as typical for sweet sorghum. Physical agronomic attributes and juice quality were measured biweekly at milk (Mi), soft dough (SD), hard dough (HD), physiological maturity (PM), and postphysiological maturities (PPM). Harvestable stalk counts were measured when stalks reached Mi 
stage and normalized to one hectare. On each harvest date, sampling consisted of 30 stalks (three bundles of 10 stalks) selected at random, and hand-harvested using a cane knife from each plot. Seed-heads (top and axillary) were removed to simulate what will likely occur during industrial harvesting with a sugarcane combine harvester equipped with a top cutter. Each stalk bundle and seed heads were weighed separately to determine fresh weight yields and grain yields $(\mathrm{Mg} / \mathrm{ha})$, respectively, and to determine crop yields. Stalk heights and diameters $\left(3^{\text {rd }}, 7^{\text {th }}\right.$, and $12^{\text {th }}$ internodes) of ten representative whole stalks were measured using a 12-foot measuring table and digital calipers, respectively. After measuring the physical dimensions of the stalk on each harvest date and physiological crop maturity (Table 1), a bundle with leaves intact was crushed twice through a Squier ${ }^{\mathrm{TM}}$ (Buffalo, NY) three-roller mill at Ardoyne Farm (Schriever, LA). First and second expressed juices were collected for each bundle and combined. The juice was filtered through a $0.6 \mathrm{~mm}$ mesh filter. Juice was weighed, placed on ice, and transported to the USDAARS-SRRC laboratory in New Orleans, LA for further processing. Aliquots of juice were also immediately stored in a $-80{ }^{\circ} \mathrm{C}$ freezer until further analysis.

\subsection{Brix, pH, Color, Turbidity, Assimilable Nitrogen, Phosphate, Conductivity Ash, Total Organic Carbon, Total Nitrogen}

Brix was measured in triplicate with a temperature-controlled refractometer (model TCR 1530; Index Instruments, FL) to an accuracy of \pm 0.01 Brix. Juice $\mathrm{pH}$ was measured in triplicate with a Metrohm Brinkman 716 DMS Titrino (Riverview, FL) and a Mettler Toledo (Columbus, $\mathrm{OH})$ xerolyte electrode. Color was determined in triplicate according to the official ICUMSA method GS2/3-9 (2011), in which $25 \mathrm{~mL}$ of filtered juice $(0.45 \mu \mathrm{m}$ filter) was mixed with $35 \mathrm{~mL}$ of triethanoloamine/ hydrochloric acid buffer $(\mathrm{pH} \mathrm{7})$ and absorbance read at $420 \mathrm{~nm}$. Color was also measured at $\mathrm{pH} 4$ and $\mathrm{pH} 9$ after adjusting the solution with $0.1 \mathrm{M} \mathrm{HCl}$ and $0.1 \mathrm{M} \mathrm{NaOH}$, respectively. Nephelometer turbidity (NTU) was measured in triplicate using a Hach 2100N turbidimeter (Loveland, CO). Yeast assimilable nitrogen (YAN) was analyzed in triplicate (Abernathy et al., 2009). Phosphate $\left(\mathrm{P}_{2} \mathrm{O}_{5}\right)$ was determined in triplicate using a colorimetric assay based on the measurement of phosphate-molybdenum blue complex at $700 \mathrm{~nm}$ (ICUMSA, 1994). Conductivity ash was measured in triplicate on filtered juices $(0.45 \mu \mathrm{m}$ filter) without dilution, using a YSI 3200 conductivity meter (Yellow Springs, OH). The total organic carbon (TOC)/nitrogen (TN) content of the filtered juices $(0.45 \mu \mathrm{m}$ filter) were performed in triplicate with a Torch Combustion TOC/TN analyzer (Teledyne Tekmar, Mason, $\mathrm{OH}$ ) after adjusting the total soluble solids content to $10 \mathrm{~g} \mathrm{~L}^{-1}$ and diluted 1:100 with deionized water. All analyses were conducted at room temperature unless otherwise stated in the methods.

\subsection{Fermentable Sugars}

Glucose, fructose, and sucrose in juice samples were determined in four replicates using high performance anion exchange chromatography with integrated pulsed amperometric detection (HPAEC-IPAD) following the method reported by Andrzejewski et al. (2013b). Prior to analysis, juice was filtered through a $0.45 \mu \mathrm{m}$ PVDF filter and diluted $(1: 5000, \mathrm{v} / \mathrm{v})$ with deionized water before analysis with a Dionex ${ }^{\mathrm{TM}}$ ICS5000+ (Dionex-Thermo Scientific, Sunnyvale, CA) with a CarboPac PA-1 ${ }^{\mathrm{TM}}$ analytical $(250 \mathrm{x} 4 \mathrm{~mm})$ and guard columns $(50 \mathrm{x} 4 \mathrm{~mm})$ and $100 \mathrm{mM} \mathrm{NaOH}$ eluent. Mannitol (20 ppm) was used as an internal standard. Total fermentable sugars or invert sugars ( $\mathrm{SO}$, glucose and fructose, $\mathrm{g} \mathrm{L}^{-1}$ ) were determined stoichiometrically using the simplified formula in Eq. 1. Juice purity (\%) was also determined by dividing total sugars (sucrose + glucose + fructose) by Brix. 
Total Fermentable Sugars $\left(\mathrm{SO}, \mathrm{g} \mathrm{L}^{-1}\right)=([$ Sucrose $] \times 1.053)+[$ Glucose $]+[$ Fructose $]$

Eq. (1)

\subsection{Total, Soluble, and Insoluble Starch Content and Granule Size in Juices}

Total, soluble, and insoluble starch was determined according to the microwave-assisted sonication/iodometric method developed by Cole et al. (2016). Starch was assayed in triplicate, and concentrations are quoted as average g starch per kg stalk. Starch granule size was measured using the method reported by Eggleston et al. (2015b) with a digital microscope at 100x with a built-in $30 \mathrm{MP}$ camera (Omax, Kent, WA) after mixing $50 \mu \mathrm{L}$ of juice with $50 \mu \mathrm{L}$ filtered iodine $(0.22 \mu \mathrm{m})$. Diameters of at least 40 granules were measured to an accuracy of $\pm 1 \mu \mathrm{m}$ and sorted into histogram populations. Mean, mode, and range of starch sizes were calculated. Total starch concentration in raw sweet sorghum juice was converted to fermentable glucose using Eqs. 2 and 3.

Total Starch $\left(\mathrm{mg} \mathrm{L}^{-1}\right)=$ (Total Starch $\left(\mathrm{g} \mathrm{kg}^{-1}\right) \times$ stalk weight $\left(\mathrm{kg} \mathrm{stalk}^{-1}\right) \times$ $1000\left(\mathrm{mg} \mathrm{g}^{-1}\right) /$ extracted juice volume ( $\left.\mathrm{L} \mathrm{stalk}^{-1}\right)$

Untapped Fermentable Glucose from Total Starch $\left(\mathrm{mg} \mathrm{L}^{-1}\right)=\operatorname{Starch}\left(\mathrm{mg} \mathrm{L}^{-1}\right) \times 1.10 \quad$ Eq. (3)

\subsection{Values for Potential Ethanol and Profits}

Theoretical values of ethanol (mL EtOH L ${ }^{-1}$ juice) in raw sweet sorghum juices were determined using fermentable sugars only (SS, hydrolyzed sucrose + glucose + fructose) or with the untapped glucose added from starch (SO) using on Eqs. 2-4.

Theor. EtOH $\left(\mathrm{mL} \mathrm{L}^{-1}\right)=\mathrm{SS}$ or $\mathrm{SO}\left(\mathrm{g} \mathrm{L}^{-1}\right) \times 0.6455\left(\mathrm{~mL} \mathrm{EtOH} \mathrm{g} \mathrm{Fermentable} \mathrm{Sugars}^{-1}\right) \quad$ Eq.

\subsection{Statistics}

Each cultivar was analyzed and compared within years using two-way (cultivar and maturity) ANOVA in JMP SAS 11.2; whereas, two-year juice quality traits and yields were evaluated using multivariate (environment, cultivar, and maturity) analysis. Means were separated using Tukey's Honest Significant Difference Test to a maximum probability $(\mathrm{P})$ of 0.05 . Pearson product-moment correlation $(\mathrm{R})$ coefficients were used to assess the relationships among all cultivar quality results.

\section{Results and Discussion}

\subsection{Environmental Effects on Sweet Sorghum Growth}

The number of days between planting and Mi maturity differed by cultivar and ranged between 77-94 days, generally following the order: Dale> M81E> Theis> Top 76-6 (Table 2). Maturity rates and wet crop yields varied between the two years, which was attributable to environmental (climate) differences (Fig. A1), although soil type may have had an effect. In 2014, average temperatures were cooler and rainfall greater than in 2013 (Table 2). Although daily temperatures ranged from 23 to $32{ }^{\circ} \mathrm{C}$ (2013) and 17 to $29{ }^{\circ} \mathrm{C}$ (2014) from planting to $\mathrm{Mi}$ 
stage, average temperatures were 26.5 and $25.8{ }^{\circ} \mathrm{C}$ for 2013 and 2014 harvest seasons, respectively (Table 3). Average rainfall was greater $(\mathrm{P}<0.05)$ from planting to Mi stage in 2014 than in 2013 (Table 3). As a result, in 2014 the number of days needed to reach Mi stage among the cultivars was prolonged $(\mathrm{P}<0.05)$ by $11-27 \%$, with Top $76-6$ and Dale the least affected and $M 81 E$ the most. This result is not uncommon as sweet sorghum planted in lower temperatures grows much more slowly than in warmer climates (Guiying et al., 2000; Theivasigamani et al., 2013). Results in Table A1 show that a moderately strong correlation occurred between the number of days needed to reach Mi maturity and rainfall $(\mathrm{R}=0.666)$. The rainfall pattern observed in each year of this study indicated that crop maturation could have been mutually and adversely affected by the low total and large clustered rainfall observed in 2014 (Table 3). Similar results have been observed at Delta Biorenewables (Memphis, TN) in which low and/or clustered rainfall (>0.2 in) substantially impacted crop yield (Randy Powell, Delta Biorenewables personal communication). This may also explain the year-to-year difference for the average number of days in the field for Dale, M81E, Theis, and Top 76-6 (Table 2).

\subsection{Cultivar and Maturity Effects on Sweet Sorghum}

\subsubsection{Physical Crop Attributes}

Physical crop attributes among the sweet sorghum cultivars studied in 2013 and 2014 were significantly different at the 5\% probability level (Tables 2 and 3), and agree with previous studies (Broadhead, 1972; Han et al., 2012a, 2012b). Fresh crop yields in 2014 (43-53\%) were lower $(\mathrm{P}<0.05)$ than in $2013(52-74 \%)$ and had a moderately strong correlation $(\mathrm{R}=0.607)$ with temperature (Table A1). This is likely due to the consistent rainfall, drier soil, and warmer temperature in 2013, which have been reported to positively affect germination, seedling emergence, booting, tillering, and crop yields in southeastern USA (Duncan \& Gardner, 1984; Han et al., 2012a, 2012b, 2012c; Prasad et al., 2007). Environment also affected wet biomass yields, which were much greater in 2013 than $2014(\mathrm{P}<0.05)$ (Tables 2 and 3). Irrespective of cultivar, average wet biomass (Tables 2 and 3) were comparable to previously reported results in LA (Ricaud, 1970; Ricaud \& Arcenaux, 1990; Tew et al., 2008; Zhao et al., 2009) and mostly affected by cultivar x environmental ( $\mathrm{G}$ x E) interactions $(\mathrm{P}<0.0001)$ (Table 4). Stalk biomass, however, decreased $(\mathrm{P}<0.05)$ with increasing maturity and was attributed to senescing of green leaves and dehydration (Han et al., 2012a). Individual stalk wet weight were influenced more by cultivar $(<0.0001)$ than maturity and environment (Table 4$)$; Theis had the heaviest $(\mathrm{P}<0.05)$ stalk wet weights for both years (Table 2). It should be noted that auxiliary stalks (side tillers) may have contributed to the cultivar effect observed on stalk weights and crop yields although special care was taken to manually remove them before taking all biophysical measurements. More research is needed to evaluate the effect cultivar, maturity, and environmental interactions have on the presence of sweet sorghum auxiliary stalks and augmented starch yields. However, it is known that more auxiliary stalks will increase the total starch concentration in extracted juices and decrease processing efficiency (Eggleston et al, 2015b), and therefore, be of interest as an untapped fermentable starch resource as well. Table A1 also showed that stalk wet weight was preferentially affected more by $(\mathrm{R}=0.881)$ than rainfall $(\mathrm{R}=0.427)$, which agrees with climate results reported by Wortman and Regassa (2011) and Erickson et al. (2011). Stalk heights, on the other hand, decreased $(\mathrm{P}<0.05)$ in the following order: Theis $>$ M81E $>$ Dale $\approx$ Top $76-6$ (Table 2) and were taller $(\mathrm{P}<0.05)$ in 2013 than 2014. Stalk height is strongly affected by the environment $(<0.0001)$ (Table 4), which may explain the $9-11 \%$ average height reduction between years. 
Internodal stalk diameters were affected mostly by $\mathrm{G} x \mathrm{E}$ interactions $(<0.0001)$, however, as the diameter narrowed in the direction towards the stalk top, cultivar $(<0.0001)$ became more prevalent (Table 4). Similar findings have been reported by Audilakshmi et al. (2010) and Eggleston et al. (2017), in which average stalk diameters correlated strongly with stalk wet weight $(\mathrm{R}=0.896)$ but weakly with height $(\mathrm{R}<0.300)$ (Table A1).

\subsubsection{Juice Extraction}

The average amount of juice extracted from sweet sorghum stalks ranged from 29 to $35 \%$ and 30 to $38 \%$ in 2013 and 2014, respectively (Table 2), and agrees with results reported by Cifuentes et al. (2014). The greatest overall juice extraction yield by cultivar and maturity was found to be $M 81 E$ and at SD, respectively (Table 2); the percent moisture retained in the bagasse varied slightly, but significantly $(\mathrm{P}<0.05)$ among each cultivar $($ Table 2$)$. This finding was attributed to stalk hardness, which has been found to increase with increasing maturity as it is known that, in practice, early season crop is almost always easier to mill than late season crop (Randy Powell, Delta Biorenewables, personal communication). This may indicate a slight, but possible, cultivar effect on roller-mill extraction yields which must be confirmed with more studies. Overall, juice extraction was relatively low and was mostly influenced by environment and maturity (E x M) interactions (Table 4). Extraction yields could be improved with imbibition water or other extraction methods such as diffusion (Eggleston et al., 2013; Jia et al., 2013; Powell, 2016).

\subsubsection{Brix and Fermentable Sugars}

Juice Brix, a measure of soluble solids content in the extracted juices, was variable and irreproducible between years, maturity, and cultivar $(\mathrm{P}<0.05)$. On average, Brix values were $\sim 21 \%$ higher in 2013 than in 2014 (Tables 2 and 3) and reflected the usual juice Brix observed in southeastern LA (Han et al., 2012a; Kim and Day, 2011). Higher Brix values, however, have been reported in other locations across the U.S. with these same cultivars (Matt Heckemeyer, Heckemeyer Mill, personal communication; Randall Powell, Delta Biorenewables, personal communication; Teetor et al., 2011; Wang et al., 2014). The low juice Brix and respective differences between 2013 and 2014 values observed in this study, as compared to other locations, was most likely due to differences in environment and agronomy practices. Brix of the extracted juice from the cultivars also decreased $(\mathrm{P}<0.05)$ Dale $>$ Theis $\geq$ Top 76-6> M81E (Table 2) and varied slightly $(\mathrm{P}<0.05)$ among crop maturities, with the highest Brix at PM (Table 3). Brix values, as expected, correlated strongly with days to maturity $(\mathrm{R}=0.799)$, wet biomass weight $(\mathrm{R}=0.740)$, and crop yield $(\mathrm{R}=0.749)$, but showed moderate to weak correlations with other crop physical attributes (Table A1). Brix was greatly influenced by $\mathrm{G} \times \mathrm{E}$ at the $0.01 \%$ probability level (Table 4), which explains the variable juice Brix observed between harvest years and geographic locations.

Juice purities (\%, total sugars divided by Brix) ranged between $65-81 \%$ and $51-78 \%$ for 2013 and 2014, respectively (Table 2), which are typical for sweet sorghum. More specifically, total sugars were also higher $(\mathrm{P}<0.05)$ in 2013 than in 2014 , despite the high variability among results and inconsistent Brix values between years (Fig. 1). Total sugars, however, were greatest at HD and most abundant in Top 76-6 for both years (Fig. 1). Top 76-6 also had the highest amount of invert sugars (glucose and fructose) in 2013, but in 2014 had equally abundant invert sugars as Theis and M81E ( $\mathrm{P}<0.05)$. As expected, sucrose was the dominant sugar in all of the mature 2013 and 2014 sweet sorghum juices, but was lower in 2014 (Fig. 1). This agrees with 
Teetor et al. (2011) and Han et al. (2012a) who also reported sucrose dominance in mature sweet sorghum. However, in contrast to findings by Han et al. (2012a), glucose never exceeded the sucrose concentration in immature sweet sorghum in this study. Among the three soluble sugars for all cultivars studied, sucrose correlated the strongest with juice Brix ( $R=0.850)$, most likely because it was the most abundant (Table A1). Correlations listed in Table A1 also show that temperature strongly affected total sugar content in sweet sorghum juices $(R=0.897)$, which may be due to preferential production of sucrose $(\mathrm{R}=0.813)$. The markedly lower total sugars extracted in sweet sorghum juices in 2014 may have been due to the colder weather and different rainfall patterns. Interestingly, glucose, fructose, and sucrose concentrations were individually influenced by $\mathrm{G} \times \mathrm{E}$ interactions $(<0.0001)$ whereas, total sugars were most affected by $\mathrm{G} \times \mathrm{M}$ interactions $(<0.0001)$ (Table 4). Results in Table A1 show that fermentable sugars only correlated weakly and moderately with Brix $(\mathrm{R}=0.569)$ and Brix sugars $(\mathrm{R}=0.720)$, respectively (Table A1). Therefore, although a common practice, using juice Brix as an in-field harvesting indicator to predict stalk maturity may present bias to sweet sorghum cultivars that were bred specifically for crystalline sugar (high sucrose) rather than syrup production (high glucose) (Lime, 1979), because it does not account for the environmental or maturity effects that are unique to each fermentable sugar or the total sugar that varies crop-to-crop and measures all soluble components in juice not accurately measuring sugars. Thus, it is important to develop an in-field, breeding, or industrial method that accurately measures all fermentable sugars rather than soluble impurities in sweet sorghum juice that can effectively evaluate syrup and fermentation potential.

\subsubsection{Starch}

Extracted juices in 2013 contained nearly two-fold more starch than in 2014 (Fig. 2), with starch yields among the four sweet sorghum cultivars ranging from $50-315 \mathrm{~g} / \mathrm{kg}$ plant or $0.8-21.3$ $\mathrm{g} \mathrm{L}^{-1}$ juice (Fig. 2). This was greater than the 76-154 g/kg starch range reported by Alves et al. (2014). Difference among starch quantities in juice may be due to the different starch methods used to measure total, soluble, and insoluble starches in sweet sorghum juice (Cole et al., 2016) in addition to cultivar, crop maturity, harvesting environment (USA vs Brazil), or part of the plant (Alves et al., 2014). In this study, it is also likely that the total starch determined in the juices included the insoluble starch contributed from axillary seed-heads (side tillers) and/or green leaves that were still intact during roller-milling of the stalks. Eggleston et al. (2017) showed that axillary seed-heads significantly increased sweet sorghum starch content and were detrimental to processing. It was also shown that that protein rich green leaves among other trash actually facilitated juice settling and clarification despite augmenting juice color and turbidity (Eggleston et al., 2015a, 2015c).

Starch was lowest at Mi stage for both years, before doubling at SD (Fig. 2). A moderate inverse correlation between the number of days needed for the crop to reach Mi maturity and total starch per plant mass ( $\mathrm{R}=-0.770)$ was also observed (Table A1). The concentration of starch in extracted juices was more affected by $\mathrm{G}$ x E interactions $(<0.0001)$ than maturity (Table 4), which may be attributable to cultivar-specific photosynthetic pathways that govern the production of starch but have not been proven (Bihmidine et al., 2013; Shakoor et al., 2014; Slewinski, 2012). Total starch in sweet sorghum juices decreased significantly by cultivar: Dale> M81E> Theis $>$ Top 76-6 (Fig. 2), and were slightly affected by rainfall ( $\mathrm{R}=-0.577)$ but not temperature $(\mathrm{R}=0.315)$ (Table A1). Fig. 2 also shows that $M 81 E$ produced 2-3 times more total starch than Dale in 2013, but was susceptible to the unfavorable rainfall and colder climate in 
2014 and suffered a dramatic decrease in total starch content, which misrepresents the attainable untapped fermentable potential of M81E in Fig. 3. Total starch concentration (Table A1) correlated strongly and inversely with glucose $(\mathrm{R}=-0.893)$ and may be related to glucose utilization during starch biosynthesis $(\mathrm{R}=-0.684)$.

Majority of the total starch in the extracted juices was insoluble (Fig. A2) varying $(\mathrm{P}<0.05)$ between $83-96 \%$ among the cultivars studied; results agree with previous reports (Eggleston et al., 2015a, 2017). Insoluble starch sizes ranged from 0.50 to $9.6 \mu \mathrm{m}$ among cultivars and maturity stages with average diameters from 2.5 to $3.5 \mu \mathrm{m}$ (Fig. A3). In this study, $\geq 80 \%$ of the insoluble starch in the extracted juice measured was $<5 \mu \mathrm{m}$ (Fig. A3). Starch size increased $(\mathrm{P}<0.05)$ by cultivar Theis $\leq$ Top $76-6 \leq$ Dale $<$ M81E (Fig. A3-A). The largest starch granules were observed at the SD, HD, and PM stages (Fig. A3-B) and attributable to axillary seedheads. It is known that both starch quantity and granule size $(\sim 1.0-20.0 \mu \mathrm{m}$, but mostly $<2.6 \mu \mathrm{m})$ can negatively affect processing at later maturities, particularly juice turbidity and viscosity (Andrzejewski et al., 2013b; Eggleston et al., 2015a, 2017). A few reports have also discussed the negative impact green leaves and seedheads have on sweet sorghum juice quality, processing, and sugar yields (Eggleston, et al., 2013, 2015a, 2017; Viator et al., 2014), but none have reported the influence of these materials on starch quantities in sweet sorghum juices. Future studies are now needed to evaluate how green leaves and axillary seedheads affect starch content in juices by maturity, cultivar, and extraction method. Results obtained will be very useful in determining whether milling, diffusion, or mashes are most suitable for extracting fermentable sugars and untapped sugars from starch to maximize fermentation yields.

\subsubsection{Other Sweet Sorghum Juice Quality Traits}

Other quality attributes such as juice $\mathrm{pH}$, conductivity ash, yeast assimilable nitrogen (YAN), total organic nitrogen/carbon (TN/TOC), soluble phosphate, and turbidity were studied because of their critical roles in processing and/or fermentation yields (Table A3). In this study, there was no significant difference in juice $\mathrm{pH}$ among the four cultivars or at the different maturities (Tables 2 and 3), which could be attributable to seasonal differences or juice quality, as $\mathrm{pH}$ was strongly affected by E x M interactions (Table 4). Results listed in Table A1 show that moderate correlations existed between $\mathrm{pH}$ and wet biomass $(\mathrm{R}=0.634)$, sucrose concentration $(\mathrm{R}=0.642)$, TOC $(\mathrm{R}=0.493)$, and temperature $(\mathrm{R}=0.615)$. Weak correlations between conductivity ash and the other juice qualities (Table A1) suggest that charged juice solutes may be an insignificant indicator of the overall sweet sorghum juice quality. More studies are needed to understand the role $\mathrm{E} \times \mathrm{G} \times \mathrm{M}$ interactions have on specific inorganic and organic ions in extracted sweet sorghum juices and its effect on saccharification and liquefaction of starch and processing byproducts and/or their subsequent fermentation. This is especially important since it is known that sweet sorghum is rich in aconitic acid, which is capable of complexing to divalent ions and affecting the availability of certain processing chemical aids, enzyme cofactors, or fermentation nutrients/inhibitors (Amorim et al., 2011). Since inhibitors may be concentrated in processing by-products despite the large quantities of starch, fermentation may still be challenged reducing the overall untapped fermentation potential and economical value of starch.

Yeast assimilable nitrogen (YAN) and total nitrogen $(\mathrm{TN})$ in the extracted juices were governed by E x M interactions $(<0.0001)$ (Table 4), in which the greatest TN and YAN amounts were extracted at SD maturity (Table A3). Raw juices contained medium to high TN and low YAN (Table A3) and indicates that these cultivars, if grown in southeastern LA under similar environmental conditions, may require YAN supplementation during raw juice fermentation. The 
total organic carbon (TOC) in the extracted juices, which measures all organic carbon matter that may be utilized during fermentation, fermentation inhibitors (e.g., acids, alcohols, indigestible matter, etc.), as well as non-fermentable sugars, was influenced more by the environment rather than cultivar or maturity stage $(\mathrm{P}<0.05)$. Likewise, phosphate ranged from $43-84 \mathrm{ppm}$ and according to Andrzejewski et al., (2013a), it may not be enough for clarification or fermentation without additional supplementation from phosphoric acid. Phosphate concentration was governed mainly by maturity $(<0.0001)$, although a cultivar effect $(<0.0001)$ was present (Table 4) which also agreed with Andrzejewski et al. (2013b). As expected, juice turbidity was affected by plant impurities, i.e., soil, stalk, leaves, pith or microbes, that can be extracted with sweet sorghum juice by harvesting and roller-milling (Andrzejewski et al., 2013a, 2013b; Billa et al., 1997; Eggleston et al., 2014) and did not vary significantly ( $>>0.05)$ between harvesting years (Table A3). In fact, it was found that raw juice turbidity was affected mostly by cultivar interactions $(<0.0001)$, without much effect from crop maturity or environment (Table 4). Nonetheless, turbid plant impurities in processing by-products can still have an adverse affect on fermentation yields and the utilization of untapped starch particularly if they contain microbes or enzymes that inhibit saccharification and/or fermentation processes.

\subsection{Theoretical Ethanol Yields from Fermentable Soluble Sugars and Untapped Fermentable Glucose from Starch}

Theoretical ethanol $(\mathrm{EtOH})$ yields predicted from (i) invert sugars + hydrolyzed sucrose (sugars only, SO) and (ii) SO + hydrolyzed starch (sugars with starch sugars, SS) in extracted sweet sorghum juice varied significantly $(\mathrm{P}<0.05)$ by cultivar and maturity (Fig. 3$)$. When SO was considered, average EtOH values decreased by cultivar in this order: Top 766>Dale $>$ Theis $>M 81 E$ (Fig. 3). Top 76-6 and Theis demonstrated steady increases in theoretical EtOH from SD to PPM (Fig. 3). In dramatic contrast, Dale and M81E exhibited inconsistent EtOH yields with increasing maturity and HD and PPM were better maturities for higher juice fermentation yields (Fig. 3). However, the high volume of EtOH estimated at PPM is likely due to a concentration effect on sugars caused by the older, dehydrated stalk, as these values were based on the total extractable juice volume. For all cultivars, theoretical EtOH increased from $\sim 6$ to $17 \%$ when SS was considered, in which the highest theoretical volume of EtOH was attributed to Dale, but the highest \% increase in $\mathrm{EtOH}$ was attributed to $M 81 E$ (Fig. 3). This result was expected since both Dale and M81E contained the most amount of starch per $100 \mathrm{~mL}$ juice.

Starch in raw sweet sorghum juices and processing by-products can theoretically augment the commercial value of sweet sorghum juice and bioproduct yields, but will vary by cultivar. Environment, cultivar, and maturity all strongly affected theoretical fermentation and bioconversion, but maturity had the least impact. Higher starch containing cultivars, Dale and $M 81 E$ exhibited the greatest increases in theoretical EtOH yields from starch, and thus, showed potential to augment bioproduct yields, e.g., ethanol. More research is warranted to consider whether saccharification, liquefaction, and fermentation of untapped fermentable glucose from starch are economically feasible to current sweet sorghum bioprocessing efforts considering the new year-to-year Ex G x M interactions and is the focus of an upcoming study. Research is also needed to determine the effects of fermentation inhibitors and/or nonfermentable sugars on sweet sorghum bioprocessing. In dramatic contrast, Top 76-6 was the better cultivar for syrup manufacture, while it did demonstrate some small potential to augment $\mathrm{EtOH}$ yields.

\section{Conclusions}


Four commercial cultivars of sweet sorghum, grown on land following sugarcane cultivation practices in southeast Louisiana, were compared for biomass, agronomic characteristics, juice quality attributes, and potential theoretical ethanol yields with consideration of the untapped fermentable sugars from insoluble starch. Five crop maturities, i.e., milk, soft dough, hard dough, physiological maturity, and post-physiological maturity, were studied because they overlap the typical and ideal harvest period for sweet sorghum. Numerous crop growth indicators were found to be moderately or strongly correlated to juice quality attributes, specifically days to reach milk maturity, Brix, and total juice sugars, and were largely affected by environmental and cultivar interactions. The amount of starch in the extracted juices was mostly in the insoluble form $(>95 \%)$, varied $(\mathrm{P}<0.05)$ by cultivar, and was inversely related to the days required to reach milk maturity. This indicated that a cultivar and maturity effect governs the untapped fermentable value of starch. Other quality attributes such as bagasse moisture, stalk height, assimilable nitrogen, and $\mathrm{pH}$ were implicated by environmental and maturity interactions which can adversely affect processing and/or fermentation. Total sugars and juice phosphates were influenced by cultivar and maturity interactions, which may explain why previously reported sweet sorghum juice clarification and evaporation were dramatically affected by cultivar and maturity. Theoretical ethanol yields, considering glucose and fructose only, indicated that Top 76-6 is a better cultivar for syrup production since it (i) contains the least amount of starch, (ii) can likely be harvested at all crop maturities, and (iii) is less likely to have processing problems. Cultivars Dale and M81E, however, are more attractive for fermentation since their high starch content can be used to augment the economical value of sweet sorghum from 3-31\%. Optimal harvesting maturities, based on two year averages and all cultivars, occurred between SD and HD maturities. More studies are now warranted to understand the value of starch in fermentation processes, from processing products and by-products, and whether or not other juice extraction methods enable better quality juices, change starch quantities in juices, or are affected by the same parameters as roller-milling. Considering that there is a strong cultivar effect on processing and starch augmentation of ethanol yields, in addition to the quantity of other critical fermentation parameters, more studies are also needed to understand the economical value of these crops across the entire manufacturing and biorefinery streams.

\section{Acknowledgements}

The authors graciously thank Mr. Norris Matherne and Mr. Clinton Randall at the USDA Sugarcane Research Unit for assisting with crop management, harvesting, and taking biophysical measurements of the sweet sorghum for both years. We also thank Mrs. Deborah Boykin for her help on statistical analysis. Also, we appreciate Mr. Eldwin St. Cyr, Ms. Alexa Triplett, and Mrs. Lynda Wartelle for assisting in analytical sample preparation and transporting samples. This research did not receive any specific grant from funding agencies in the public, commercial, or not-for-profit sectors. Mention of trade names, commercial products, or methods in this article is solely for the purpose of providing specific information and does not imply recommendation or endorsement by the U.S. Department of Agriculture (USDA). USDA is an equal opportunity provider and employer.

\section{References}


1. Abernathy, D. G., Spedding, G., \& Starcher, B. (2009). Analysis of protein and total usable nitrogen in beer and wine using a microwell ninhydrin assay. J. Inst. Brew., 115(2), 122-127.

2. Alves, F. V., Polesi, L. F., Aguiar, C. L., \& Sarmento, S. B. S. (2014). Structural and physicochemical characteristics of starch from sugar cane and sweet sorghum stalks. Carbohydr. Polym., 111(10), 592-597.

3. Amorim, H. V., Lopes, M. L., Oliveira, J. V., Buckeridge, M. S., \& Goldman, G. H. (2011) Scientific challenges of bioethanol production in Brazil. Appl. Microb. Biotech. 91:1267-1275.

4. Andrzejewski, B., Eggleston, G., Lingle, S., \& Powell, R. (2013a). Development of a sweet sorghum juice clarification method in the manufacture of industrial feedstocks for value-added fermentation products. Ind. Crops Prod., 44(0), 77-87.

5. Andrzejewski, B., Eggleston, G., \& Powell, R. (2013b). Pilot plant clarification of sweet sorghum juice and evaporation of raw and clarified juices. Ind. Crops Prod., 49, 648658.

6. Audilakshmi, S., Mall, A. K., Swarnalatha, M., \& Seetharama, N. (2010). Inheritance of sugar concentration in stalk (Brix), sucrose content, stalk and juice yield in sorghum. Biomass \& Bioenerg., 34(6), 813-820.

7. Bihmidine, S., Hunter, C. T., Johns, C. E, Koch, K. E., Braun, D. M. (2013). Regulation of assimilate import into sink organs: update on molecular drivers of sink strength. Front. Plant Sci. 4(177), 1-15.

8. Billa, E., Koullas, D. P., Monties, B., \& Koukios, E. G. (1997). Structure and composition of sweet sorghum stalk components. Ind. Crops Prod, , 6(3-4), 297-302.

9. Broadhead, D. M., Coleman, O. H., \& Freeman, K. C. (1970). Dale, a new variety of sweet sorghum for sirup production (Information Sheet No. 1099) (pp. 1-2). Meridian, Mississippi: U.S. Sugar Crops Field Station, Mississippi State University, Agricultural Experiment Station.

10. Broadhead, D. M. (1972). Effect of planting date and maturity on juice quality of Rio sweet sorghum. Agron. J., 64(3), 389-390.

11. Broadhead, D. M., Freeman, K. C., Coleman, O., \& Zumo, N. (1974). Theis - a new variety of sweet sorghum for sirup production (Information Sheet No. 1236) (pp. 1-2). Meridian, Mississippi: U.S. Sugar Crops Field Station, Mississippi State University, Agricultural Experiment Station. Retrieved from http://msucares.com/crops/sorghum/Theis_descripton.pdf

12. Broadhead, D. M., Freeman, K. C., \& Zummo, N. (1981). M81E - a new variety of sweet sorghum (Information Sheet No. 1309) (pp. 1-4). Meridian, Mississippi: U.S. Sugar Crops Field Station, Mississippi State University, Agricultural Experiment Station. Retrieved from http://msucares.com/crops/sorghum/M81E_description.pdf

13. Chen, J. C. P., \& Chou, C. C. (1993). Chemicals used as sugar processing aids. In Cane Sugar Handbook: A Manual for Cane Sugar Manufacturers and Their Chemists (12th ed.). John Wiley \& Sons, Inc.

14. Cifuentes, R., Bressani, R., \& Rolz, C. (2014). The potential of sweet sorghum as a source of ethanol and protein. Energ. Sus. Develop., 21, 13-19.

15. Cole, M., Eggleston, G., Gilbert, A., \& Chung, Y. J. (2016). Development of an analytical method to measure insoluble and soluble starch in sugarcane and sweet sorghum products. Food Chem., 190(1), 50-59. 
16. Day, J. L., Duncan, R. R., R. R., Raymer, P. L., Lovell, G. G., Thompson, D. S., Garrett, H. D., \& Zummo, N. (1995). Top 76-6: A new sweet sorghum variety for sirup production (Research Report No. 634) (pp. 1-5). The Georgia Agricultural Experiment Stations, College of Agricultural and Environmental Sciences, The University of Georgia.

17. Duncan, R. R., \& Gardner, W. A. (1984). The influence of ratoon cropping on sweet sorghum yield, sugar production, and insect damage. Canad. J. Plant Sci., 64(2), 261274.

18. Eggleston, G., Cole, M., \& Andrzejewski, B. (2013). New commercially viable processing technologies for the production of sugar feedstocks from sweet sorghum (Sorghum bicolor L. Moench) for manufacture of biofuels and bioproducts. Sugar Tech, 15(3), 232-249.

19. Eggleston, G., Legendre, D., Pontif, K., \& Gober, J. (2014). Improved control of sucrose losses and clarified juice turbidity with lime saccharate in hot lime clarification of sugarcane juice and other comparisons with milk of lime. J. Food Proc. Preserv., 38(1), 311-325.

20. Eggleston, G., Heckemeyer, M., St. Cyr, E., \& Wartelle, L. (2015a). Case study: Commercialization of sweet sorghum juice clarification for large-scale syrup manufacture. Sugar Tech, 1-9.

21. Eggleston, G., Wartelle, L., Cole, M., Montes, B., \& Pontif, K. (2015b). From juice to sugar: How insoluble and soluble starch really changes across sugarcane factories. Internat. Sugar J., In Review.

22. Eggleston, G., Andrzejewski, B., Cole, M., Dalley, C., Sklanka, S., St. Cyr, E., ... Powell, R. (2015c). Novel Storage Technologies for raw and clarified sweet sorghum syrups manufactured under pilot plant conditions. Biomass \& Bioenerg., 81, 424-436.

23. Eggleston, G., Rao, K., Wartelle, L., Zatlokovicz, J., Schneeberger, R., Petrie, E., Cole, M., St. Cyr, E. (2017). Quality and processing attributes of sweet sorghum biomass for large-scale biorefineries: A comparison of hybrids and a commercial cultivar. Proc. Adv. Sugar Crop Proc. Conv., in press.

24. Erickson, J. E., Helsel, Z. R., Woodard, K. R., Vendramini, J. M. B., Wang, Y., Sollenberger, L. E., \& Gilbert, R. A. (2011). Planting date affects biomass and Brix of sweet sorghum grown for biofuel across Florida. Agron. J., 103(6), 1827-1833.

25. Guiying, L., Weibin, G., Hicks, A., \& Chapman, K. R. (2000). A training manual for sweet sorghum. Bangkok, Thailand: FAO/CAAS/CAS.

26. Han, K. J., Alison, M. W., Pitman, W. D., Day, D. F., Kim, M., \& Madsen, L. (2012a). Planting date and harvest maturity impact on biofuel feedstock productivity and quality of sweet sorghum grown under temperate Louisiana conditions. Agron. J., 104(6), 16181624.

27. Han, K. J., Alison, W. M., Day, D., \& McCormick, M. E. (2012b). Planting and harvest management impact sweet sorghum as a biofuel crop. Presented at the In 2012 AFGC Annual Conference Proceedings and Abstracts [CD-ROM computer file], 2012 AFGC Annual Conference.

28. Han, K. J., Pitman, W. D., Alison, M. W., Harrell, D. L., Viator, H. P., McCormick, M. E., Gravois, K., Kim, M., Day, D. F. (2012c). Agronomic considerations for sweet sorghum biofuel production in the south-central USA. Bioenerg. Res., 5(3), 748-758. 
29. ICUMSA. (1994). Total and soluble phosphate in cane juice by a colorimetric method (No. GS7-15) (pp. 1-3). United Kingdom: ICUMSA.

30. ICUMSA. (2011). Determination of the solution colour of raw sugars, brown sugars, and coloured syrups at pH 7.0-Official (No. GS2/3-9). United Kingdom: ICUMSA.

31. Jia, F., Chawhuaymak, J., Riley, M., Zimmt, W., \& Ogden, K. (2013). Efficient extraction method to collect sugar from sweet sorghum. J. Biol. Eng., 7(1), 1.

32. Kim, M., \& Day, D. (2011). Composition of sugar cane, energy cane, and sweet sorghum suitable for ethanol production at Louisiana sugar mills. J. Ind. Microbiol. Biotechnol, 38(7), 803-807.

33. Lime, B. J. (1979). Raw sugar production from sugarcane and sweet sorghum. In G. E. I. Charalambous (Ed.), Tropical Food: Chemistry and Nutrition (pp. 171-183). Academic

Press. Retrieved from http://www.sciencedirect.com/science/article/pii/B9780123709011500155

34. Linton, J. A., Miller, J. C., Little, R. D., Petrolia, D. R., \& Coble, K. H. (2011). Economic feasibility of producing sweet sorghum as an ethanol feedstock in the southeastern United States. Biomass \& Bioenerg., 35(7), 3050-3057.

35. Powell, R. (2016). Enhancing sweet sorghum sugar extraction using roll mill imbibition [Powerpoint slides]. Retrieved from Sweet Sorghum Association Annual Conference, Orlando, FL.

36. Prasad, S., Singh, A., Jain, N., \& Joshi, H. C. (2007). Ethanol production from sweet sorghum syrup for utilization as automotive fuel in India. Energ. Fuels, 21(4), 24152420.

37. Ricaud, R. (1970). Sweet sorghum for sugar production in Louisiana. Louisiana Agriculture, Louisiana Ag. Expt. Stn., Baton Rouge, LA, 14(2), 4-7.

38. Ricaud, R., \& Arcenaux, A. (1990). Sweet sorghum research on biomass and sugar production in 1990 (Manuscript report from the St. Gabriel Experiment Station).

39. Shakoor, N., Nair, R., Crasta, O., Morris, G., Feltus, A., \& Kresovich, S. (2014). A Sorghum bicolor expression atlas reveals dynamic cultivar-specific expression profiles for vegetative tissues of grain, sweet and bioenergy sorghums. BMC Plant Biol., 14(1), 35.

40. Slewinski, T. (2012) Non-structural carbohydrate partitioning in grass stems: a target to increase yield stability, stress tolerance, and biofuel production. J. Exp. Bot. 63(13), 4647-4670.

41. Teetor, V. H., Duclos, D. V., Wittenberg, E. T., Young, K. M., Chawhuaymak, J., Riley, M. R., \& Ray, D. T. (2011). Effects of planting date on sugar and ethanol yield of sweet sorghum grown in Arizona. Ind. Crops Prod., 34(2), 1293-1300.

42. Tew, T., Cobill, R., \& Richard, E., Jr. (2008). Evaluation of sweet sorghum and sorghum $\times$ sudangrass hybrids as feedstocks for ethanol production. BioEnerg. Res., 1(2), 147152.

43. Viator, H. P., Lu, S., \& Aragon, D. (2014). Influence of panicles and leafy material on sweet sorghum juice quality. J. ASSCT, In Press.

44. Wang, M. L., Cole, M., Tonnis, B., Pinnow, D., Xin, Z., Davis, J., Hung, Y-C., Yu, J., Pederson, G. A., Eggleston, G. (2014). Comparison of stem damage and carbohydrate composition in the stem juice between sugarcane and sweet sorghum harvested before and after late fall frost. J. Sust. Bioenerg. Sys., 4, 161-174. 
45. Wortmann, C. S., \& Regassa, T. (2011). Economic effects of biofuel production. InTech. Retrieved from http://www.intechopen.com/books/economic-effects-of-biofuelproduction/sweet-sorghum-as-a-bioenergy-crop-for-the-us-great-plains

46. Zhao, Y. L., Dolat, A., Steinberger, Y., Wang, X., Osman, A., \& Xie, G. H. (2009). Biomass yield and changes in chemical composition of sweet sorghum cultivars grown for biofuel. Field Crops Res., 111(1-2), 55-64. 
Table 1. Dates that sweet sorghum was harvested in Schriever, Louisiana, by cultivar and maturity, in 2013 and 2014.

\begin{tabular}{|c|c|c|c|c|c|}
\hline & \multicolumn{5}{|c|}{ Harvest Dates per Crop Maturity } \\
\hline Cultivar & Mi & SD & HD & PM & PPM \\
\hline \multirow{3}{*}{ Dale } & $8 / 1 / 2013$ & $8 / 15 / 2013$ & $8 / 29 / 2013$ & $9 / 12 / 2013$ & $9 / 26 / 2013$ \\
& $7 / 30 / 2014$ & $8 / 13 / 2014$ & $8 / 27 / 2014$ & $9 / 10 / 2014$ & $9 / 24 / 2014$ \\
\hline \multirow{3}{*}{ M81E } & $8 / 15 / 2013$ & $8 / 29 / 2013$ & $9 / 12 / 2013$ & $9 / 26 / 2013$ & $10 / 17 / 2013$ \\
& $8 / 27 / 2014$ & $9 / 10 / 2014$ & $9 / 24 / 2014$ & $10 / 7 / 2014$ & $10 / 22 / 2014$ \\
& & & & & \\
\hline \multirow{3}{*}{ Theis } & $8 / 15 / 2013$ & $8 / 29 / 2013$ & $9 / 12 / 2013$ & $9 / 26 / 2013$ & $10 / 17 / 2013$ \\
& $8 / 20 / 2014$ & $9 / 2 / 2014$ & $9 / 16 / 2014$ & $9 / 30 / 2014$ & $10 / 14 / 2014$ \\
\hline \multirow{3}{*}{ Top 76-6 } & $8 / 29 / 2013$ & $9 / 12 / 2013$ & $9 / 26 / 2013$ & $10 / 17 / 2013$ & $10 / 31 / 2013$ \\
& $8 / 27 / 2014$ & $9 / 10 / 2014$ & $9 / 24 / 2014$ & $10 / 7 / 2014$ & $10 / 22 / 2014$ \\
\hline
\end{tabular}


Table. 2. Agronomic, crop performance, physical, and juice quality attributes of sweet sorghum by cultivar during 2013 and 2014 seasons.

\begin{tabular}{|c|c|c|c|c|c|c|c|c|c|c|c|c|}
\hline \multicolumn{5}{|c|}{$2013^{*}$} & \multicolumn{4}{|c|}{2014} & \multicolumn{4}{|c|}{ Two-Year Average } \\
\hline Parameter & Dale & $M 81 E$ & Theis & Top 76-6 & Dale & $M 81 E$ & Theis & Top 76-6 & Dale & M81E & Theis & Top 76-6 \\
\hline Days to Milk & $83^{\mathrm{C}}$ & $97^{\mathrm{B}}$ & $97^{\mathrm{B}}$ & $111^{\mathrm{A}}$ & $96^{\mathrm{C}}$ & $123^{\mathrm{A}}$ & $116^{\mathrm{B}}$ & $123^{\mathrm{A}}$ & $90^{\mathrm{C}}$ & $110^{\mathrm{B}}$ & $107^{\mathrm{B}}$ & $117^{\mathrm{A}}$ \\
\hline Days in Field & $139^{\mathrm{C}}$ & $161^{\mathrm{B}}$ & $161^{\mathrm{B}}$ & $174^{\mathrm{A}}$ & $150^{\mathrm{C}}$ & $178^{\mathrm{A}}$ & $170^{\mathrm{B}}$ & $178^{\mathrm{A}}$ & $145^{\mathrm{B}}$ & $170^{\mathrm{A}}$ & $166^{\mathrm{AB}}$ & $176^{\mathrm{A}}$ \\
\hline Crop Yield (Stalks/ha) & $89,100^{\mathrm{B}}$ & $103,100^{\mathrm{A}}$ & $72,500^{\mathrm{C}}$ & $90,000^{\mathrm{B}}$ & $73,500^{\mathrm{A}}$ & $70,700^{\mathrm{B}}$ & $64,000^{\mathrm{C}}$ & $60,000^{\mathrm{D}}$ & $81,300^{\mathrm{A}}$ & $86,900^{\mathrm{A}}$ & $68,250^{\mathrm{A}}$ & $75,000^{\mathrm{A}}$ \\
\hline Crop Yield (\%) ${ }^{* *}$ & $64^{\mathrm{B}}$ & $74^{\mathrm{A}}$ & $52^{\mathrm{C}}$ & $64^{\mathrm{B}}$ & $53^{\mathrm{A}}$ & $51^{\mathrm{B}}$ & $46^{\mathrm{C}}$ & $43^{\mathrm{CD}}$ & $58^{\mathrm{AB}}$ & $62^{\mathrm{A}}$ & $49^{\mathrm{C}}$ & $54^{\mathrm{B}}$ \\
\hline Biomass $(M g / h a)$ & $68^{\mathrm{BC}}$ & $84^{\mathrm{A}}$ & $64^{\mathrm{C}}$ & $71^{\mathrm{B}}$ & $43^{\mathrm{B}}$ & $43^{\mathrm{B}}$ & $45^{\mathrm{B}}$ & $48^{\mathrm{A}}$ & $55^{\mathrm{B}}$ & $63^{\mathrm{A}}$ & $55^{\mathrm{B}}$ & $60^{\mathrm{AB}}$ \\
\hline $\begin{array}{l}\text { Stalk Weight (g/10 } \\
\text { stalks) }\end{array}$ & $7,599^{\mathrm{B}}$ & $8,128^{\mathrm{B}}$ & $8,798^{\mathrm{B}}$ & $7,933^{\mathrm{B}}$ & $5,800^{\mathrm{C}}$ & $6,176^{\mathrm{C}}$ & $7,029^{\mathrm{B}}$ & $8,046^{\mathrm{A}}$ & $6,699^{\mathrm{B}}$ & $7,152^{\mathrm{B}}$ & $8,012^{\mathrm{A}}$ & $7,990^{\mathrm{A}}$ \\
\hline $\begin{array}{l}\text { Extraction Efficiency } \\
(\%)\end{array}$ & $29.2^{\mathrm{C}}$ & $32.4^{\mathrm{B}}$ & $32.0^{\mathrm{B}}$ & $35.4^{\mathrm{A}}$ & $30.4^{\mathrm{C}}$ & $30.8^{\mathrm{C}}$ & $32.3^{\mathrm{B}}$ & $38.2^{\mathrm{A}}$ & $29.8^{\mathrm{D}}$ & $31.6^{\mathrm{C}}$ & $33.4^{\mathrm{B}}$ & $36.8^{\mathrm{A}}$ \\
\hline Bagasse Moisture (\%) & $64.3^{\mathrm{A}}$ & $60.3^{\mathrm{B}}$ & $62.5^{\mathrm{AB}}$ & $57.0^{\mathrm{C}}$ & $66.8^{\mathrm{A}}$ & $65.0^{\mathrm{B}}$ & $62.2^{\mathrm{C}}$ & $65.3^{\mathrm{B}}$ & $65.6^{\mathrm{A}}$ & $63.0^{\mathrm{B}}$ & $62.3^{\text {B }}$ & $61.7^{\text {B }}$ \\
\hline Juice Yield (L/ha) & $19,830^{\mathrm{C}}$ & $29,081^{\mathrm{A}}$ & $20,942^{\mathrm{C}}$ & $26,435^{\mathrm{B}}$ & $13,209^{\mathrm{C}}$ & $13,626^{\mathrm{C}}$ & $15,917^{\mathrm{B}}$ & $18,091^{\mathrm{A}}$ & $18,359^{\mathrm{C}}$ & $25,646^{\mathrm{A}}$ & $20,007^{\mathrm{B}}$ & $24,495^{\mathrm{A}}$ \\
\hline Juice Brix & $13.73^{\mathrm{A}}$ & $13.59^{\mathrm{A}}$ & $12.91^{\mathrm{B}}$ & $13.93^{\mathrm{A}}$ & $12.51^{\mathrm{A}}$ & $8.67^{\mathrm{D}}$ & $10.98^{\mathrm{B}}$ & $9.92^{\mathrm{C}}$ & $13.01^{\mathrm{A}}$ & $10.98^{\mathrm{C}}$ & $11.91^{\mathrm{B}}$ & $11.59^{\mathrm{B}}$ \\
\hline Juice $p H$ & $5.82^{\mathrm{A}}$ & $5.90^{\mathrm{A}}$ & $6.26^{\mathrm{A}}$ & $6.08^{\mathrm{A}}$ & $5.33^{\mathrm{B}}$ & $5.24^{\mathrm{C}}$ & $5.41^{\mathrm{A}}$ & $5.19^{\mathrm{C}}$ & $5.40^{\mathrm{AB}}$ & $5.33^{\mathrm{B}}$ & $5.53^{\mathrm{A}}$ & $5.32^{\mathrm{B}}$ \\
\hline Juice Purity (\%) & $75.5^{\mathrm{B}}$ & $69.5^{\mathrm{C}}$ & $80.9^{\mathrm{A}}$ & $80.4^{\mathrm{AB}}$ & $51.7^{\mathrm{C}}$ & $77.7^{\mathrm{A}}$ & $62.7^{\mathrm{B}}$ & $69.5^{\mathrm{B}}$ & $63.4^{\mathrm{B}}$ & $72.7^{\mathrm{AB}}$ & $72.5^{\mathrm{AB}}$ & $75.9^{\mathrm{A}}$ \\
\hline Juice Turbidity (NTU) & $4,100^{\mathrm{A}}$ & $3,691^{\mathrm{B}}$ & $3,857^{\mathrm{AB}}$ & $2,094^{\mathrm{C}}$ & $5,678^{\mathrm{A}}$ & $2,491^{\mathrm{B}}$ & $2,420^{\mathrm{B}}$ & $2,766^{\mathrm{B}}$ & $4,889^{\mathrm{A}}$ & $3,091^{\mathrm{B}}$ & $3,138^{\mathrm{B}}$ & $2,430^{\mathrm{C}}$ \\
\hline Height $(\mathrm{cm})$ & $339^{\mathrm{B}}$ & $370^{\mathrm{A}}$ & $372^{\mathrm{A}}$ & $341^{\mathrm{B}}$ & $313^{\mathrm{C}}$ & $328^{\mathrm{B}}$ & $368^{\mathrm{A}}$ & $311^{\mathrm{C}}$ & $325^{\mathrm{C}}$ & $351^{\mathrm{B}}$ & $371^{\mathrm{A}}$ & $325^{\mathrm{C}}$ \\
\hline $\begin{array}{l}\text { 3rd Node Diameter } \\
(\mathrm{cm})\end{array}$ & $1.96^{\mathrm{B}}$ & $2.06^{\mathrm{A}}$ & $2.00^{\mathrm{B}}$ & $1.98^{\mathrm{B}}$ & $1.76^{\mathrm{C}}$ & $1.86^{\mathrm{B}}$ & $1.86^{\mathrm{B}}$ & $2.08^{\mathrm{A}}$ & $1.86^{\mathrm{C}}$ & $1.96^{\mathrm{B}}$ & $1.94^{\mathrm{B}}$ & $2.03^{\mathrm{A}}$ \\
\hline $\begin{array}{l}\text { 7th Node Diameter } \\
(\mathrm{cm})\end{array}$ & $1.65^{\mathrm{C}}$ & $1.81^{\mathrm{A}}$ & $1.76^{\mathrm{B}}$ & $1.67^{\mathrm{C}}$ & $1.38^{\mathrm{C}}$ & $1.54^{\mathrm{B}}$ & $1.53^{\mathrm{B}}$ & $1.83^{\mathrm{A}}$ & $1.52^{\mathrm{C}}$ & $1.68^{\mathrm{B}}$ & $1.65^{\mathrm{B}}$ & $1.75^{\mathrm{A}}$ \\
\hline $\begin{array}{l}\text { 12th Node Diameter } \\
(\mathrm{cm})\end{array}$ & $1.14^{\mathrm{D}}$ & $1.29^{\mathrm{B}}$ & $1.35^{\mathrm{A}}$ & $1.20^{\mathrm{C}}$ & $0.94^{\mathrm{C}}$ & $1.21^{\mathrm{B}}$ & $1.23^{\mathrm{B}}$ & $1.43^{\mathrm{A}}$ & $1.04^{\mathrm{C}}$ & $1.25^{\mathrm{B}}$ & $1.29^{\mathrm{A}}$ & $1.32^{\mathrm{A}}$ \\
\hline $\begin{array}{l}\text { Average Diameter } \\
(\mathrm{cm})\end{array}$ & $1.58^{\mathrm{B}}$ & $1.72^{\mathrm{A}}$ & $1.70^{\mathrm{A}}$ & $1.62^{\mathrm{B}}$ & $1.36^{\mathrm{C}}$ & $1.54^{\mathrm{B}}$ & $1.54^{\mathrm{B}}$ & $1.78^{\mathrm{A}}$ & $1.47^{\mathrm{C}}$ & $1.63^{\mathrm{B}}$ & $1.62^{\mathrm{B}}$ & $1.70^{\mathrm{A}}$ \\
\hline $\begin{array}{l}\text { Average Temperature } \\
\left({ }^{\circ} \mathrm{C}\right)\end{array}$ & $2.66^{\mathrm{AB}}$ & $2.66^{\mathrm{A}}$ & $2.66^{\mathrm{A}}$ & $2.65^{\mathrm{B}}$ & $2.59^{\mathrm{A}}$ & $2.58^{\mathrm{A}}$ & $2.59^{\mathrm{A}}$ & $2.58^{\mathrm{A}}$ & $2.62^{\mathrm{A}}$ & $2.62^{\mathrm{A}}$ & $2.63^{\mathrm{A}}$ & $2.62^{\mathrm{A}}$ \\
\hline Average Rainfall $(\mathrm{cm})$ & $24.7^{\mathrm{C}}$ & $26.0^{\mathrm{B}}$ & $26.0^{\mathrm{B}}$ & $27.4^{\mathrm{C}}$ & $17.8^{\mathrm{B}}$ & $19.2^{\mathrm{B}}$ & $23.3^{\mathrm{A}}$ & $22.0^{\mathrm{A}}$ & $21.5^{\mathrm{B}}$ & $22.6^{\mathrm{B}}$ & $24.7^{\mathrm{A}}$ & $24.7^{\mathrm{A}}$ \\
\hline
\end{tabular}

"Mean results followed by the same upper case letter within rows are compared within year or two-year average and are not significantly different at the $5 \%$ probability level. ${ }^{* *}$ Crop yield $(\%)$ was calculated by dividing the number of stalks per hectare by 140,000 . 
Table. 3. Agronomic, crop performance, physical, juice quality attributes of sweet sorghum by maturity during 2013 and 2014 seasons.

\begin{tabular}{|c|c|c|c|c|c|c|c|c|c|c|c|c|c|c|c|}
\hline \multirow[b]{2}{*}{ Parameter } & \multicolumn{5}{|c|}{2013} & \multicolumn{5}{|c|}{2014} & \multicolumn{5}{|c|}{ Two-Year Average } \\
\hline & Mi & SD & HD & PM & PPM & Mi & SD & HD & PM & PPM & Mi & SD & HD & PM & PPM \\
\hline Days in Field & $96^{\mathrm{D}}$ & $110^{\mathrm{CD}}$ & $123^{\mathrm{BC}}$ & $139^{\mathrm{AB}}$ & $157^{\mathrm{A}}$ & $115^{\mathrm{D}}$ & $127^{\mathrm{CD}}$ & $141^{\mathrm{BC}}$ & $155^{\mathrm{AB}}$ & $169^{\mathrm{A}}$ & $105^{\mathrm{D}}$ & $119^{c}$ & $132^{\mathrm{BC}}$ & $147^{\mathrm{B}}$ & $163^{\mathrm{A}}$ \\
\hline Crop Yield (Stalks/ha) & \multicolumn{5}{|c|}{$88,675^{\mathrm{A}}$} & \multicolumn{5}{|c|}{$67,026^{\mathrm{B}}$} & \multicolumn{5}{|c|}{$77,851^{\ddagger}$} \\
\hline Crop Yield (\%) & \multicolumn{5}{|c|}{$63^{\mathrm{A}}$} & \multicolumn{5}{|c|}{$48^{\mathrm{B}}$} & \multicolumn{5}{|c|}{$56^{\ddagger}$} \\
\hline Biomass $(\mathrm{Mg} / \mathrm{ha})$ & $84^{\mathrm{A}}$ & $76^{\mathrm{B}}$ & $70^{\mathrm{BC}}$ & $68^{\mathrm{CD}}$ & $61^{\mathrm{D}}$ & $44^{\mathrm{B}}$ & $47^{\mathrm{A}}$ & $47^{\mathrm{A}}$ & $39^{\mathrm{C}}$ & $46^{\mathrm{AB}}$ & $64^{\mathrm{A}}$ & $62^{\mathrm{AB}}$ & $59^{\mathrm{ABC}}$ & $54^{\mathrm{C}}$ & $55^{\mathrm{C}}$ \\
\hline Stalk Weight (kg/10 stalks) & $9.51^{\mathrm{A}}$ & $8.61^{\mathrm{B}}$ & $7.91^{\mathrm{C}}$ & $7.60^{\mathrm{C}}$ & $6.95^{\mathrm{D}}$ & $6.69^{\mathrm{A}}$ & $7.16^{\mathrm{A}}$ & $7.14^{\mathrm{A}}$ & $5.98^{\mathrm{B}}$ & $6.78^{\mathrm{A}}$ & $8.10^{\mathrm{A}}$ & $7.89^{\mathrm{B}}$ & $7.52^{\mathrm{BC}}$ & $6.79^{\mathrm{C}}$ & $6.88^{\mathrm{C}}$ \\
\hline Extraction Efficiency (\%) & $30.0^{\mathrm{B}}$ & $35.3^{\mathrm{A}}$ & $34.3^{\mathrm{A}}$ & $31.2^{\mathrm{B}}$ & $30.5^{\mathrm{B}}$ & $31.3^{\mathrm{B}}$ & $33.0^{\mathrm{AB}}$ & $35.5^{\mathrm{A}}$ & $33.5^{\mathrm{AB}}$ & $35.0^{\mathrm{A}}$ & $30.6^{\mathrm{A}}$ & $34.1^{\mathrm{AB}}$ & $34.9^{\mathrm{A}}$ & $32.4^{\mathrm{BC}}$ & $32.4^{\mathrm{BC}}$ \\
\hline Bagasse Moisture (\%) & $64.5^{\mathrm{A}}$ & $62.6^{\mathrm{A}}$ & $58.7^{\mathrm{B}}$ & $54.2^{\mathrm{C}}$ & $64.3^{\mathrm{A}}$ & $61.4^{\mathrm{C}}$ & $67.0^{\mathrm{A}}$ & $63.7^{\mathrm{B}}$ & $66.9^{\mathrm{A}}$ & $66.0^{\mathrm{A}}$ & $62.9^{\mathrm{B}}$ & $64.8^{\mathrm{A}}$ & $61.4^{\mathrm{C}}$ & $62.1^{\mathrm{BC}}$ & $65.3^{\mathrm{A}}$ \\
\hline Juice Yield (L/ha) & $25,752^{\mathrm{B}}$ & $27,994^{\mathrm{A}}$ & $25,191^{\mathrm{B}}$ & $21,557^{\mathrm{C}}$ & $19,360^{\mathrm{D}}$ & $13,587^{\mathrm{B}}$ & $15,843^{\mathrm{A}}$ & $17,222^{\mathrm{A}}$ & $13,367^{\mathrm{B}}$ & $16,078^{\mathrm{A}}$ & $23,048^{\mathrm{B}}$ & $25,294^{\mathrm{A}}$ & $23,420^{\mathrm{B}}$ & $19,737^{\mathrm{C}}$ & $18,745^{\mathrm{C}}$ \\
\hline Juice Brix & $11.36^{\mathrm{D}}$ & $13.33^{\mathrm{C}}$ & $14.38^{\mathrm{AB}}$ & $14.75^{\mathrm{A}}$ & $14.03^{\mathrm{B}}$ & $11.21^{\mathrm{A}}$ & $10.46^{\mathrm{B}}$ & $10.55^{\mathrm{B}}$ & $10.61^{\mathrm{B}}$ & $9.91^{\mathrm{C}}$ & $11.23^{\mathrm{D}}$ & $11.78^{\mathrm{C}}$ & $12.19^{\mathrm{AB}}$ & $12.30^{\mathrm{A}}$ & $11.95^{\mathrm{BC}}$ \\
\hline Juice $\mathrm{pH}$ & $5.62^{\mathrm{B}}$ & $5.84^{\mathrm{AB}}$ & $6.27^{\mathrm{A}}$ & $6.14^{\mathrm{A}}$ & $6.19^{\mathrm{A}}$ & $5.31^{\mathrm{AB}}$ & $5.35^{\mathrm{A}}$ & $5.31^{\mathrm{AB}}$ & $5.22^{\mathrm{C}}$ & $5.26^{\mathrm{BC}}$ & $5.36^{\mathrm{A}}$ & $5.42^{\mathrm{A}}$ & $5.45^{\mathrm{A}}$ & $5.35^{\mathrm{A}}$ & $5.36^{\mathrm{A}}$ \\
\hline Juice Purity (\%) & $80.6^{\mathrm{A}}$ & $72.1^{\mathrm{C}}$ & $80.1^{\mathrm{A}}$ & $64.8^{\mathrm{D}}$ & $76.6^{\mathrm{B}}$ & $63.0^{\mathrm{B}}$ & $52.4^{\mathrm{C}}$ & $58.3^{\mathrm{BC}}$ & $57.9^{\mathrm{BC}}$ & $72.1^{\mathrm{A}}$ & $71.8^{\mathrm{A}}$ & $62.3^{\mathrm{C}}$ & $69.2^{\mathrm{AB}}$ & $61.3^{\mathrm{BC}}$ & $74.4^{\mathrm{A}}$ \\
\hline Juice Turbidity (NTU) & $4,480^{\mathrm{A}}$ & $3,071^{\mathrm{C}}$ & $2,694^{\mathrm{D}}$ & $3,888^{\mathrm{B}}$ & $3,011^{\mathrm{C}}$ & $2,540^{\mathrm{D}}$ & $3,747^{\mathrm{B}}$ & $3,065^{\mathrm{C}}$ & $4,437^{\mathrm{A}}$ & $2,907^{\mathrm{C}}$ & $3,833^{\mathrm{B}}$ & $3,296^{\mathrm{C}}$ & $2,818^{\mathrm{D}}$ & $4,071^{\mathrm{A}}$ & $2,976^{\mathrm{CD}}$ \\
\hline Height $(\mathrm{cm})$ & $337^{\mathrm{C}}$ & $364^{\mathrm{A}}$ & $366^{\mathrm{A}}$ & $357^{\mathrm{B}}$ & $354^{\mathrm{B}}$ & $334^{\mathrm{A}}$ & $323^{\mathrm{B}}$ & $336^{\mathrm{A}}$ & $324^{\mathrm{B}}$ & $324^{\mathrm{B}}$ & $335^{\mathrm{C}}$ & $343^{A}$ & $351^{\mathrm{A}}$ & $340^{\mathrm{B}}$ & $340^{\mathrm{B}}$ \\
\hline $3 r d$ Node Diameter $(\mathrm{cm})$ & $2.14^{\mathrm{A}}$ & $2.03^{\mathrm{B}}$ & $2.03^{\mathrm{B}}$ & $1.91^{\mathrm{C}}$ & $1.90^{\mathrm{C}}$ & $1.77^{\mathrm{D}}$ & $1.87^{\mathrm{C}}$ & $1.94^{\mathrm{AB}}$ & $1.92^{\mathrm{BC}}$ & $1.98^{\mathrm{A}}$ & $1.96^{\mathrm{A}}$ & $1.95^{\mathrm{ABC}}$ & $1.99^{\mathrm{A}}$ & $1.91^{\mathrm{C}}$ & $1.93^{\mathrm{BC}}$ \\
\hline 7th Node Diameter (cm) & $1.83^{\mathrm{A}}$ & $1.76^{\mathrm{B}}$ & $1.76^{\mathrm{B}}$ & $1.61^{\mathrm{C}}$ & $1.64^{\mathrm{C}}$ & $1.49^{\mathrm{C}}$ & $1.60^{\mathrm{A}}$ & $1.60^{\mathrm{AB}}$ & $1.54^{\mathrm{BC}}$ & $1.65^{\mathrm{A}}$ & $1.66^{\mathrm{A}}$ & $1.68^{\mathrm{A}}$ & $1.68^{\mathrm{A}}$ & $1.57^{\mathrm{B}}$ & $1.64^{\mathrm{A}}$ \\
\hline 12th Node Diameter $(\mathrm{cm})$ & $1.83^{\mathrm{A}}$ & $1.32^{\mathrm{B}}$ & $1.20^{\mathrm{C}}$ & $1.15^{\mathrm{CD}}$ & $1.13^{\mathrm{D}}$ & $1.12^{\mathrm{D}}$ & $1.28^{\mathrm{A}}$ & $1.25^{\mathrm{AB}}$ & $1.16^{\mathrm{CD}}$ & $1.20^{\mathrm{BC}}$ & $1.27^{\mathrm{A}}$ & $1.30^{\mathrm{A}}$ & $1.23^{\mathrm{B}}$ & $1.15^{\mathrm{C}}$ & $1.16^{\mathrm{C}}$ \\
\hline Average Diameter $(\mathrm{cm})$ & $1.42^{\mathrm{A}}$ & $1.72^{\mathrm{A}}$ & $1.68^{\mathrm{A}}$ & $1.55^{\mathrm{A}}$ & $1.59^{\mathrm{A}}$ & $1.45^{\mathrm{A}}$ & $1.60^{\mathrm{A}}$ & $1.59^{\mathrm{A}}$ & $1.52^{\mathrm{A}}$ & $1.61^{\mathrm{A}}$ & $1.63^{\mathrm{A}}$ & $1.64^{\mathrm{A}}$ & $1.63^{\mathrm{A}}$ & $1.54^{\mathrm{B}}$ & $1.58^{\mathrm{AB}}$ \\
\hline Average Temperature $\left({ }^{\circ} \mathrm{C}\right)$ & $26.5^{\mathrm{B}}$ & $26.6^{\mathrm{A}}$ & $26.7^{\mathrm{A}}$ & $26.6^{\mathrm{A}}$ & $26.3^{\mathrm{C}}$ & $25.8^{\mathrm{B}}$ & $26.0^{\mathrm{A}}$ & $26.1^{\mathrm{A}}$ & $25.8^{\mathrm{B}}$ & $25.6^{\mathrm{C}}$ & $26.2^{\mathrm{B}}$ & $26.3^{\mathrm{AB}}$ & $26.4^{\mathrm{A}}$ & $26.3^{\mathrm{AB}}$ & $25.9^{\mathrm{C}}$ \\
\hline Average Rainfall $(\mathrm{cm})$ & $24.0^{\mathrm{E}}$ & $25.3^{\mathrm{D}}$ & $26.1^{\mathrm{C}}$ & $26.7^{\mathrm{B}}$ & $28.2^{\mathrm{A}}$ & $16.2^{\mathrm{D}}$ & $18.1^{\mathrm{C}}$ & $19.5^{\mathrm{C}}$ & $23.3^{\mathrm{B}}$ & $25.8^{\mathrm{A}}$ & $20.4^{\mathrm{D}}$ & $21.7^{\mathrm{CD}}$ & $22.8^{\mathrm{C}}$ & $25.0^{\mathrm{B}}$ & $27.0^{\mathrm{A}}$ \\
\hline
\end{tabular}

"Mean results followed by the same upper case letter within rows are compared within year and are not significantly different at the 5\% probability level. 
Table 4. F-statistics for effects of harvest year or environment (E), cultivar (G), and maturity (M) date on four commercial sweet sorghum cultivars and their biophysical and juice quality traits.

\begin{tabular}{|c|c|c|c|c|c|c|c|}
\hline \multicolumn{8}{|c|}{ F-Ratio $(\operatorname{Pr}>F)$} \\
\hline Parameter & $\begin{array}{c}\text { Harvest Year } \\
\text { (E) }\end{array}$ & $\begin{array}{l}\text { Maturity } \\
\text { (M) }\end{array}$ & $\begin{array}{c}\text { Cultivar } \\
\text { (G) }\end{array}$ & $\mathrm{E} \times \mathrm{M}$ & $E \times G$ & GX M & $\mathrm{E} \times \mathrm{G} \times \mathrm{M}$ \\
\hline Temperature & $\begin{array}{c}20,592.4 \\
(<0.0001)\end{array}$ & $\begin{array}{c}921.9 \\
(<0.0001)\end{array}$ & $\begin{array}{c}122.5 \\
(<0.0001)\end{array}$ & $\begin{array}{c}99.0 \\
(<0.0001)\end{array}$ & $\begin{array}{c}42.1 \\
(<0.0001)\end{array}$ & $\begin{array}{c}414.3 \\
(<0.0001) \\
\end{array}$ & $\begin{array}{c}79.3 \\
(<0.0001) \\
\end{array}$ \\
\hline Biomass & $\begin{array}{c}445.5 \\
(<0.0001)\end{array}$ & $\begin{array}{c}10.3 \\
(<0.0001)\end{array}$ & $\begin{array}{c}14.8 \\
(<0.0001)\end{array}$ & $\begin{array}{c}5.9 \\
(<0.0001)\end{array}$ & $\begin{array}{c}17.3 \\
(<0.0001)\end{array}$ & $\begin{array}{c}1.2 \\
(0.3186)\end{array}$ & $\begin{array}{c}1.4 \\
(0.1924) \\
\end{array}$ \\
\hline Stalk Wt. & $\begin{array}{c}78.1 \\
(<0.0001)\end{array}$ & $\begin{array}{c}11.2 \\
(<0.0001)\end{array}$ & $\begin{array}{c}18.8 \\
(<0.0001)\end{array}$ & $\begin{array}{c}5.6 \\
(<0.0001)\end{array}$ & $\begin{array}{c}16.9 \\
(<0.0001)\end{array}$ & $\begin{array}{c}1.2 \\
(0.2111)\end{array}$ & $\begin{array}{c}1.3 \\
(0.2679) \\
\end{array}$ \\
\hline Moisture & $\begin{array}{c}66.4 \\
(<0.0001)\end{array}$ & $\begin{array}{c}11.2 \\
(<0.0001)\end{array}$ & $\begin{array}{c}22.0 \\
(<0.0001)\end{array}$ & $\begin{array}{c}32.8 \\
(<0.0001)\end{array}$ & $\begin{array}{c}5.1 \\
(0.0073)\end{array}$ & $\begin{array}{c}8.4 \\
(<0.0001)\end{array}$ & $\begin{array}{c}10.7 \\
(<0.0001)\end{array}$ \\
\hline Height & $\begin{array}{c}107.8 \\
(<0.0001)\end{array}$ & $\begin{array}{c}6.4 \\
(0.0004)\end{array}$ & $\begin{array}{c}21.4 \\
(<0.0001)\end{array}$ & $\begin{array}{c}8.2 \\
(<0.0001)\end{array}$ & $\begin{array}{c}2.7 \\
(<0.0001)\end{array}$ & $\begin{array}{c}3.6 \\
(<0.0001)\end{array}$ & $\begin{array}{c}6.5 \\
(<0.0001) \\
\end{array}$ \\
\hline $3^{\text {rd }}$ Node Diam. & $\begin{array}{c}19.6 \\
(<0.0001) \\
\end{array}$ & $\begin{array}{c}1.5 \\
(0.3273) \\
\end{array}$ & $\begin{array}{c}7.3 \\
(0.0023) \\
\end{array}$ & $\begin{array}{c}7.4 \\
(<0.0001) \\
\end{array}$ & $\begin{array}{c}7.8 \\
(0.0012) \\
\end{array}$ & $\begin{array}{c}0.7 \\
(0.8226) \\
\end{array}$ & $\begin{array}{c}0.7 \\
(0.6761) \\
\end{array}$ \\
\hline $7^{\text {th }}$ Node Diam. & $\begin{array}{c}43.3 \\
(<0.0001) \\
\end{array}$ & $\begin{array}{c}4.0 \\
(0.0164) \\
\end{array}$ & $\begin{array}{c}17.2 \\
(<0.0001)\end{array}$ & $\begin{array}{c}4.1 \\
(0.0027) \\
\end{array}$ & $\begin{array}{c}19.6 \\
(<0.0001)\end{array}$ & $\begin{array}{c}0.5 \\
(0.8919) \\
\end{array}$ & $\begin{array}{c}1.3 \\
(0.2649) \\
\end{array}$ \\
\hline $12^{\text {th }}$ Node Diam. & $\begin{array}{c}4.8 \\
(0.0287) \\
\end{array}$ & $\begin{array}{c}6.3 \\
(0.0002)\end{array}$ & $\begin{array}{c}26.1 \\
(<0.0001)\end{array}$ & $\begin{array}{c}8.2 \\
(<0.0001)\end{array}$ & $\begin{array}{c}15.8 \\
(<0.0001)\end{array}$ & $\begin{array}{c}0.9 \\
(0.4851)\end{array}$ & $\begin{array}{c}1.6 \\
(0.1135) \\
\end{array}$ \\
\hline Juice Yield & $\begin{array}{c}41.7 \\
(<0.0001) \\
\end{array}$ & $\begin{array}{c}66.4 \\
(<0.0001)\end{array}$ & $\begin{array}{c}234.8 \\
(<0.0001) \\
\end{array}$ & $\begin{array}{c}24.7 \\
(<0.0001) \\
\end{array}$ & $\begin{array}{c}128.3 \\
(<0.0001)\end{array}$ & $\begin{array}{c}31.2 \\
(<0.0001)\end{array}$ & $\begin{array}{c}46.3 \\
(<0.0001) \\
\end{array}$ \\
\hline Brix & $\begin{array}{c}2,406.4 \\
(<0.0001) \\
\end{array}$ & $\begin{array}{c}71.9 \\
(<0.0001) \\
\end{array}$ & $\begin{array}{c}157.5 \\
(<0.0001) \\
\end{array}$ & $\begin{array}{c}147.7 \\
(<0.0001) \\
\end{array}$ & $\begin{array}{c}165.0 \\
(<0.0001)\end{array}$ & $\begin{array}{c}55.3 \\
(<0.0001) \\
\end{array}$ & $\begin{array}{c}48.1 \\
(<0.0001) \\
\end{array}$ \\
\hline Gluc. & $\begin{array}{c}294.9 \\
(<0.0001) \\
\end{array}$ & $\begin{array}{c}70.7 \\
(<0.0001)\end{array}$ & $\begin{array}{c}182.7 \\
(<0.0001) \\
\end{array}$ & $\begin{array}{c}151.3 \\
(<0.0001)\end{array}$ & $\begin{array}{c}355.1 \\
(<0.0001)\end{array}$ & $\begin{array}{c}111.4 \\
(<0.0001) \\
\end{array}$ & $\begin{array}{c}43.4 \\
(<0.0001) \\
\end{array}$ \\
\hline Fruc. $^{*}$ & $\begin{array}{c}1,468.1 \\
(<0.0001)\end{array}$ & $\begin{array}{c}312.3 \\
(<0.0001)\end{array}$ & $\begin{array}{c}390.9 \\
(<0.0001)\end{array}$ & $\begin{array}{c}247.7 \\
(<0.0001)\end{array}$ & $\begin{array}{c}645.7 \\
(<0.0001)\end{array}$ & $\begin{array}{c}158.5 \\
(<0.0001)\end{array}$ & $\begin{array}{c}54.7 \\
(<0.0001)\end{array}$ \\
\hline Suc. & $\begin{array}{c}3,630.5 \\
(<0.0001)\end{array}$ & $\begin{array}{c}162.2 \\
(<0.0001)\end{array}$ & $\begin{array}{c}45.1 \\
(<0.0001)\end{array}$ & $\begin{array}{c}74.7 \\
(<0.0001) \\
\end{array}$ & $\begin{array}{c}231.0 \\
(<0.0001)\end{array}$ & $\begin{array}{c}80.7 \\
(<0.0001) \\
\end{array}$ & $\begin{array}{c}37.2 \\
(<0.0001)\end{array}$ \\
\hline Total Sug ${ }^{*}$ & $\begin{array}{c}4,706.7 \\
(<0.0001)\end{array}$ & $\begin{array}{c}145.0 \\
(<0.0001)\end{array}$ & $\begin{array}{c}80.5 \\
(<0.0001)\end{array}$ & $\begin{array}{c}81.0 \\
(<0.0001)\end{array}$ & $\begin{array}{c}53.8 \\
(<0.0001)\end{array}$ & $\begin{array}{c}228.6 \\
(<0.0001)\end{array}$ & $\begin{array}{c}76.4 \\
(<0.0001) \\
\end{array}$ \\
\hline Total Starch & $\begin{array}{c}1,434.7 \\
(<0.0001) \\
\end{array}$ & $\begin{array}{c}318.5 \\
(<0.0001) \\
\end{array}$ & $\begin{array}{c}1,026.5 \\
(<0.0001)\end{array}$ & $\begin{array}{c}51.8 \\
(<0.0001) \\
\end{array}$ & $\begin{array}{c}532.5 \\
(<0.0001) \\
\end{array}$ & $\begin{array}{c}88.0 \\
(<0.0001) \\
\end{array}$ & $\begin{array}{c}56.3 \\
(<0.0001) \\
\end{array}$ \\
\hline Insoluble Starch & $\begin{array}{c}1,064.1 \\
(<0.0001)\end{array}$ & $\begin{array}{c}307.4 \\
(<0.0001)\end{array}$ & $\begin{array}{c}957.7 \\
(<0.0001) \\
\end{array}$ & $\begin{array}{c}51.1 \\
(<0.0001)\end{array}$ & $\begin{array}{c}558.4 \\
(<0.0001)\end{array}$ & $\begin{array}{c}86.5 \\
(<0.0001)\end{array}$ & $\begin{array}{c}61.4 \\
(<0.0001) \\
\end{array}$ \\
\hline Soluble Starch & $\begin{array}{c}3,837.5 \\
(<0.0001)\end{array}$ & $\begin{array}{c}111.8 \\
(<0.0001)\end{array}$ & $\begin{array}{c}168.9 \\
(<0.0001)\end{array}$ & $\begin{array}{c}16.9 \\
(<0.0001)\end{array}$ & $\begin{array}{c}282.9 \\
(<0.0001)\end{array}$ & $\begin{array}{c}93.8 \\
(<0.0001) \\
\end{array}$ & $\begin{array}{c}74.4 \\
(<0.0001) \\
\end{array}$ \\
\hline Turb. & $\begin{array}{c}47.9 \\
(<0.0001) \\
\end{array}$ & $\begin{array}{c}1,090.0 \\
(<0.0001)\end{array}$ & $\begin{array}{c}5,657.0 \\
(<0.0001)\end{array}$ & $\begin{array}{c}1,172.1 \\
(<0.0001)\end{array}$ & $\begin{array}{c}2,728.1 \\
(<0.0001)\end{array}$ & $\begin{array}{c}2,188.2 \\
(<0.0001)\end{array}$ & $\begin{array}{c}614.8 \\
(<0.0001) \\
\end{array}$ \\
\hline $\mathrm{N}^{*}$ & $\begin{array}{c}1,784.2 \\
(<0.0001)\end{array}$ & $\begin{array}{c}86.3 \\
(<0.0001)\end{array}$ & $\begin{array}{c}235.5 \\
(<0.0001)\end{array}$ & $\begin{array}{c}106.6 \\
(<0.0001)\end{array}$ & $\begin{array}{c}91.2 \\
(<0.0001)\end{array}$ & $\begin{array}{c}47.9 \\
(<0.0001)\end{array}$ & $\begin{array}{c}41.2 \\
(<0.0001)\end{array}$ \\
\hline $\mathrm{P}^{*}$ & $\begin{array}{c}8.7 \\
(0.0046) \\
\end{array}$ & $\begin{array}{c}76.3 \\
(<0.0001)\end{array}$ & $\begin{array}{c}53.9 \\
(<0.0001)\end{array}$ & $\begin{array}{c}2.8 \\
(0.0326) \\
\end{array}$ & $\begin{array}{c}37.6 \\
(<0.0001)\end{array}$ & $\begin{array}{c}41.6 \\
(<0.0001)\end{array}$ & $\begin{array}{c}11.2 \\
(<0.0001)\end{array}$ \\
\hline $\mathrm{pH}$ & $\begin{array}{c}3,431.9 \\
(<0.0001)\end{array}$ & $\begin{array}{c}83.9 \\
(<0.0001)\end{array}$ & $\begin{array}{c}102.2 \\
(<0.0001)\end{array}$ & $\begin{array}{c}122.2 \\
(<0.0001)\end{array}$ & $\begin{array}{c}55.1 \\
(<0.0001)\end{array}$ & $\begin{array}{c}18.4 \\
(<0.0001)\end{array}$ & $\begin{array}{c}29.7 \\
(<0.0001) \\
\end{array}$ \\
\hline
\end{tabular}

parameter abbreviations: stalk weight (St. Wt.), diameter (Diam.), glucose (Gluc.), fructose (Fruc.), sucrose (Suc.), total sugars (Total Sug.), turbidity (turb.), assimilable nitrogen (N), and phosphate $(\mathrm{P})$. 
Fig. 1. Estimated sugars from Brix and actual total fermentable sugars (glucose, fructose, and sucrose) in sweet sorghum juice extracted during 2013 and 2014 seasons at milk (Mi), soft dough (SD), hard dough (HD), physiological (PM), and post-physiological (PPM) maturities. Estimated sugar content from Brix was determined according to the Circular of the National Bureau of Standards (Bates, 1974)

Fig. 2. Total starch per wet plant mass $(\mathrm{g} / \mathrm{kg})$ and in extracted sweet sorghum juice $(\mathrm{g} / 100 \mathrm{~mL})$ by cultivar (A-D) and maturity. Letters of the same case among maturity are not statistically different at the 5\% probability level. Yearly averages (Avg) denoted with more than one asterisk $(*)$ are statistically significant at the $5 \%$ probability level.

Fig. 3. Comparison of theoretical ethanol volume (mL/L juice) from fermentations of invert sugars only (SO) and invert sugar supplemented with hydrolyzed starch sugars (SS) per cultivar, maturity, and two year averages. Asterisks $(*, * *)$ indicate significant differences between total SO and SS at the 5\% probability level. 
Fig. 1. Estimated sugars from Brix and actual total fermentable sugars (glucose, fructose, and sucrose) in sweet sorghum juice extracted during 2013 and 2014 seasons at milk (Mi), soft dough (SD), hard dough (HD), physiological (PM), and post-physiological (PPM) maturities. Estimated sugar content from Brix was determined according to the Circular of the National Bureau of Standards (Bates, 1974)

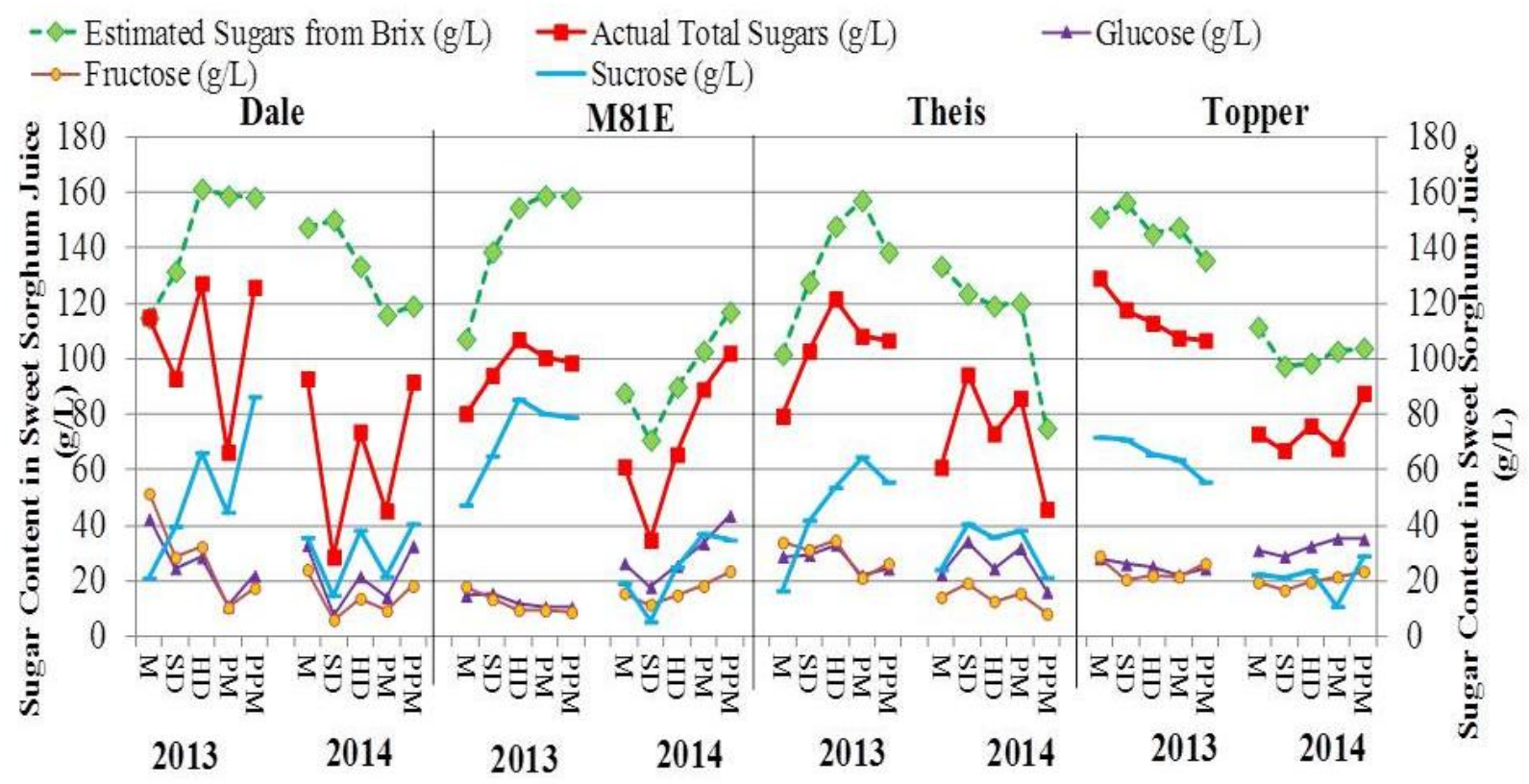


Fig. 2. Total starch per wet plant mass $(\mathrm{g} / \mathrm{kg})$ and in extracted sweet sorghum juice $(\mathrm{g} / 100 \mathrm{~mL})$ by cultivar (A-D) and maturity. Letters of the same case among maturity are not statistically different at the 5\% probability level. Yearly averages (Avg) denoted with more than one asterisk (*) are statistically significant at the $5 \%$ probability level.
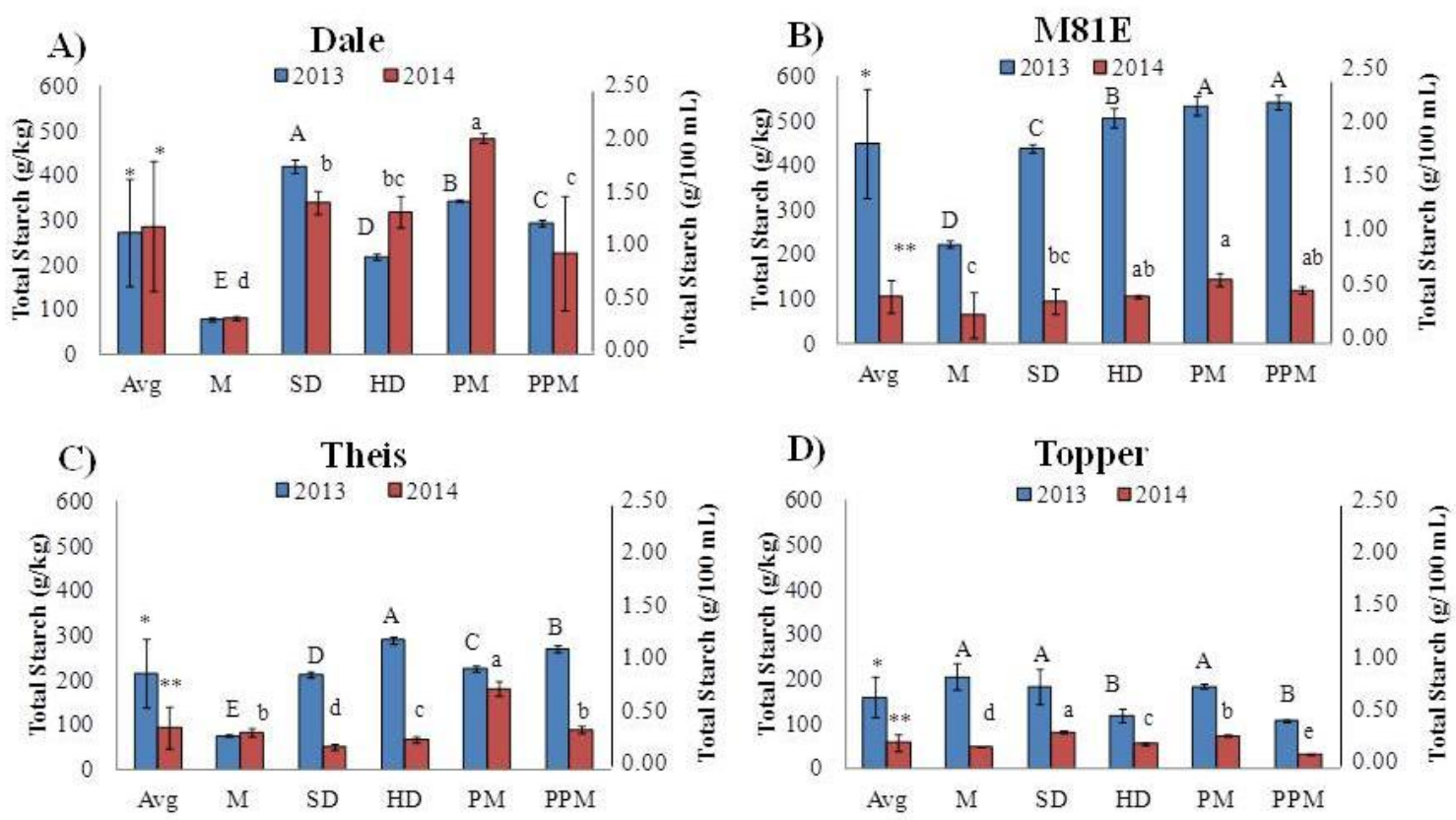
Fig. 3. Comparison of theoretical ethanol volume (mL/L juice) from fermentations of invert sugars only (SO) and invert sugar supplemented with hydrolyzed starch sugars (SS) per cultivar, maturity, and two year averages. Asterisks $(*, * *)$ indicate significant differences between total SO and SS at the 5\% probability level.

Avg. Increase in Ethanol Yields

Dale A: $12.70 \pm 2.27 \%$

MS1E B: $16.23 \pm 1.11 \%$

Theis C: $11.26 \pm 1.10 \%$

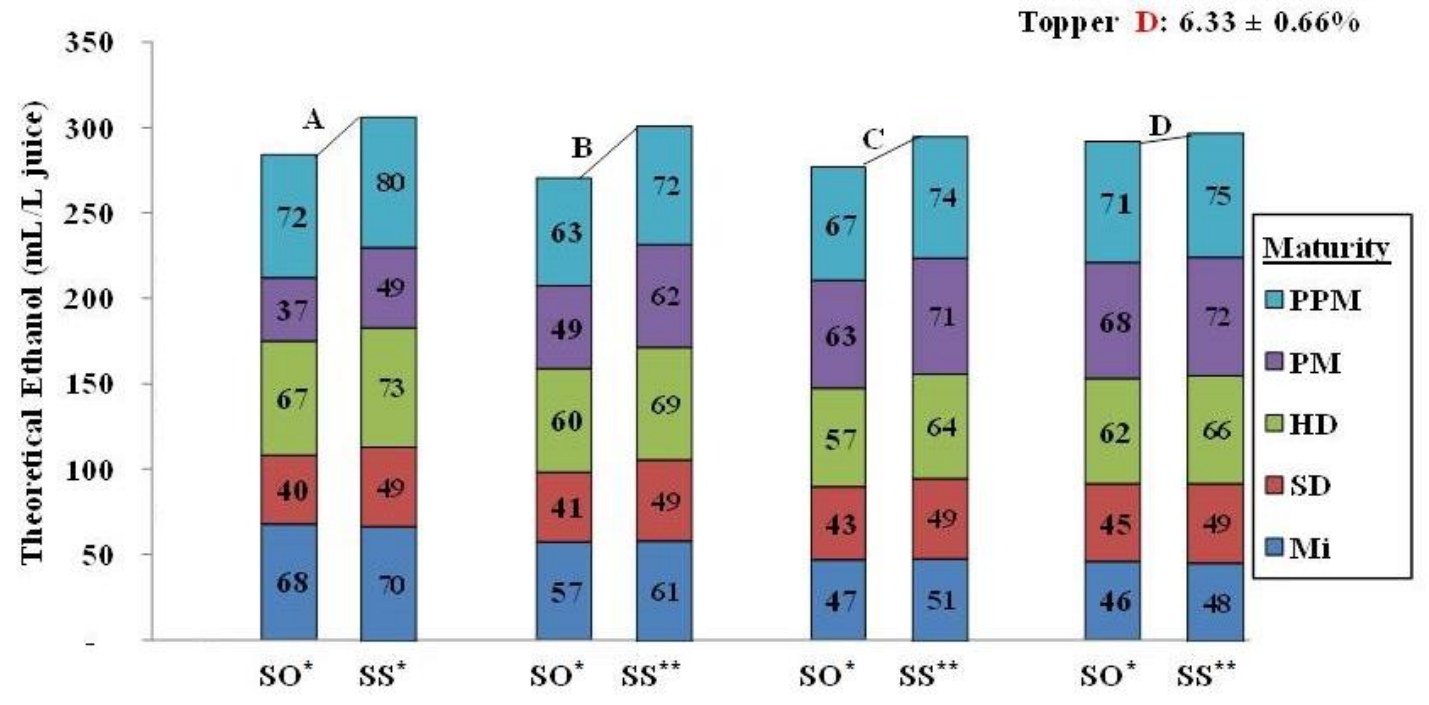




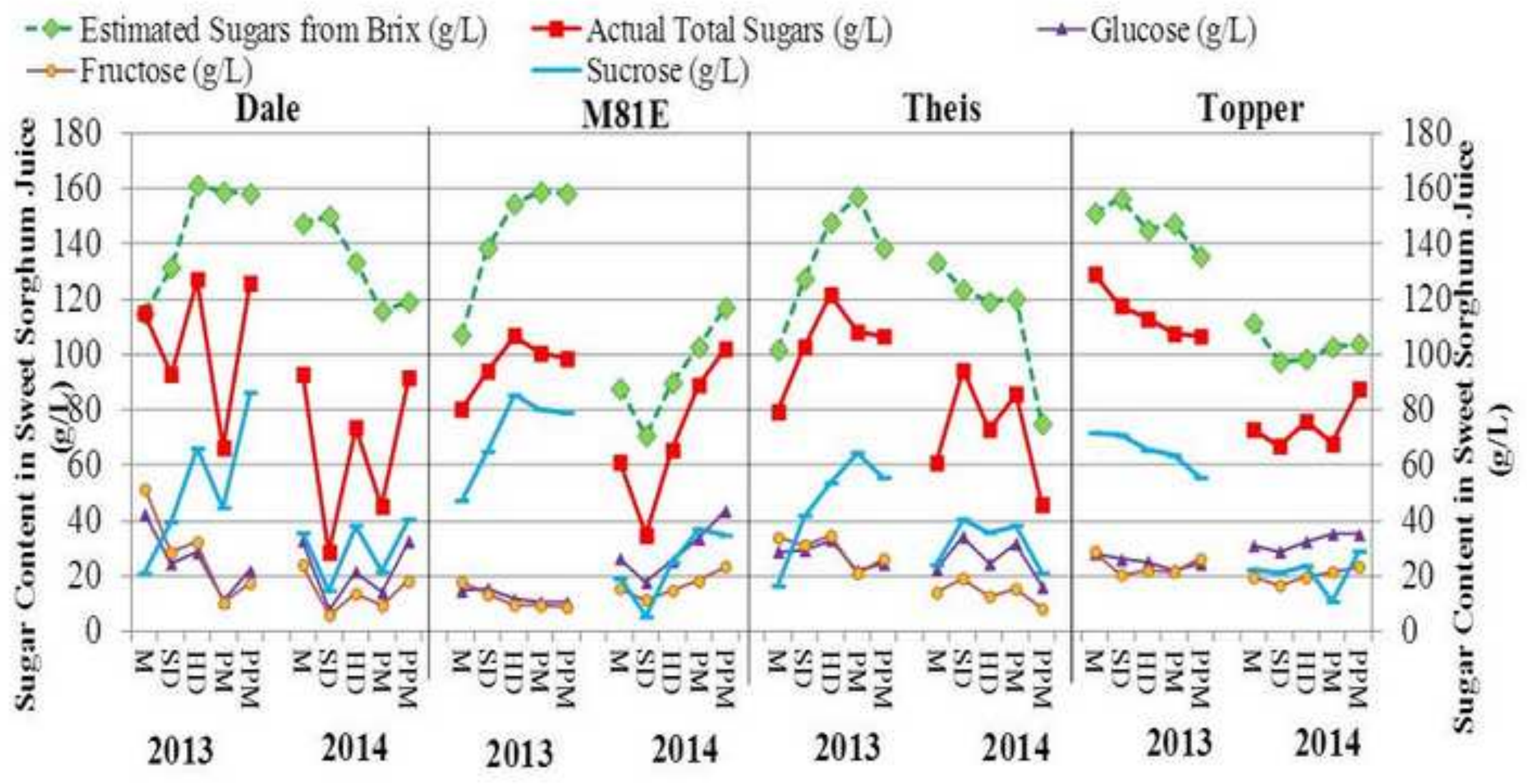



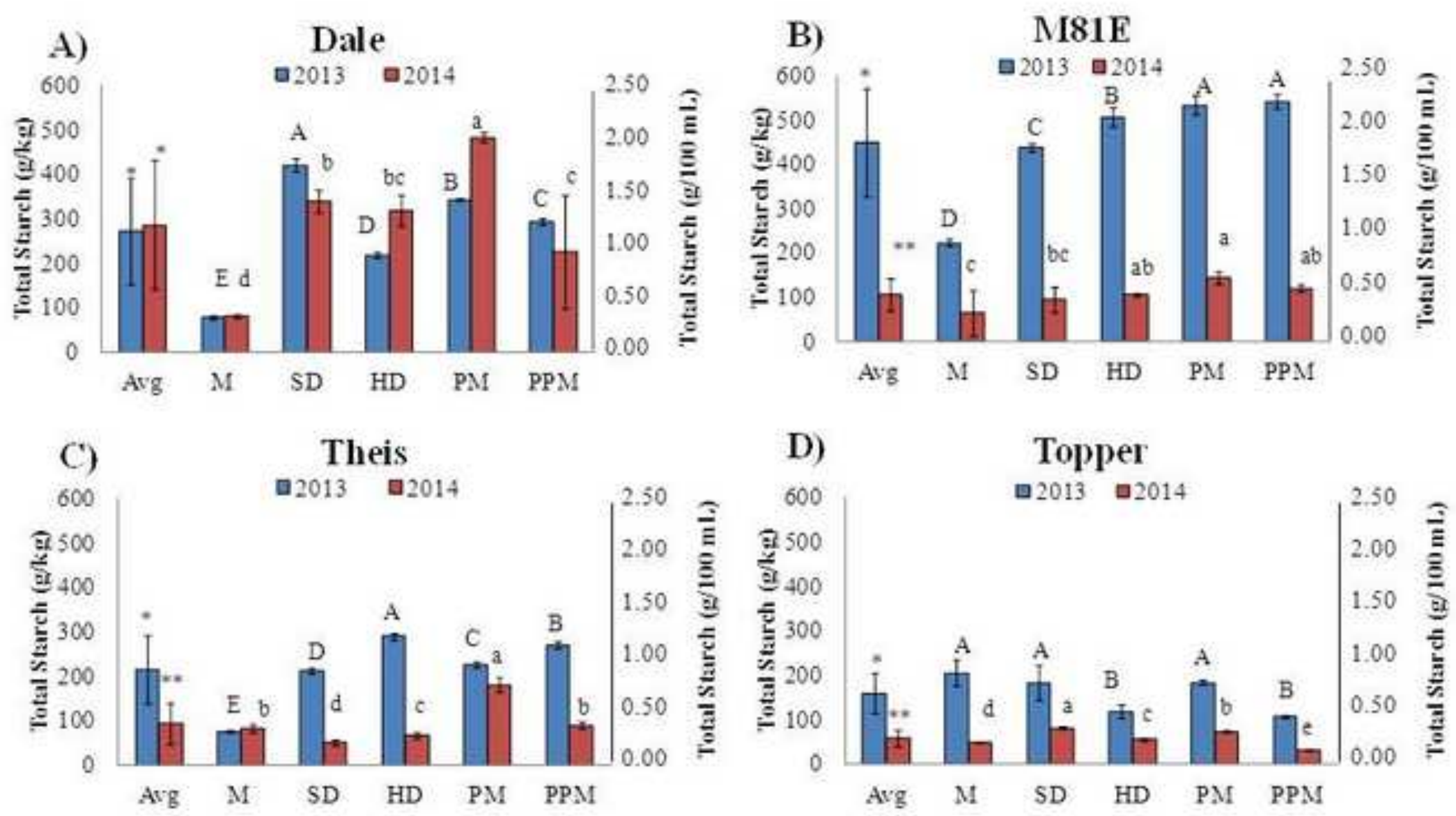
Avg. Increase in Ethanol Yields Dale A: $12.70 \pm 2.2700$

MS1E B: $16.23 \pm 1.11^{\circ} \%$

Theis C: $11.26 \pm 1.10^{\circ}$ o

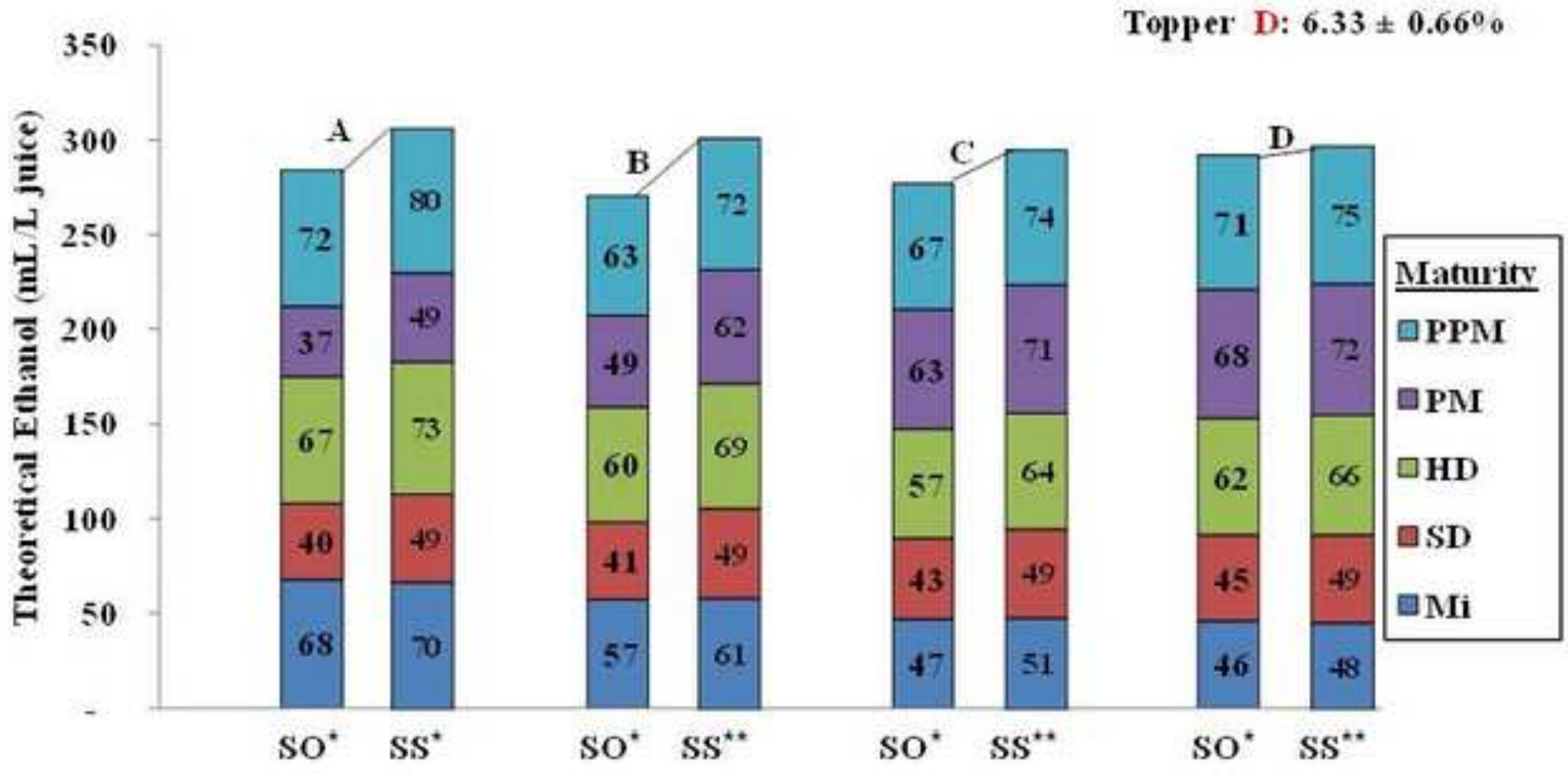


Table A1. Agronomic, crop performance, physical, and juice quality attributes of sweet sorghum by cultivar during 2013 and 2014 seasons.

\begin{tabular}{|c|c|c|c|c|c|c|c|c|c|c|c|c|}
\hline \multirow[b]{2}{*}{ Parameter } & \multicolumn{4}{|c|}{$2013^{*}$} & \multicolumn{4}{|c|}{2014} & \multicolumn{4}{|c|}{ Two-Year Average } \\
\hline & Dale & $M 81 E$ & Theis & Top 76-6 & Dale & $M 81 E$ & Theis & Top 76-6 & Dale & M81E & Theis & Top 76-6 \\
\hline Days to Milk & $83^{\mathrm{C}}$ & $97^{\mathrm{B}}$ & $97^{\mathrm{B}}$ & $111^{\mathrm{A}}$ & $96^{\mathrm{C}}$ & $123^{\mathrm{A}}$ & $116^{\mathrm{B}}$ & $123^{\mathrm{A}}$ & $90^{\mathrm{C}}$ & $110^{\mathrm{B}}$ & $107^{\mathrm{B}}$ & $117^{\mathrm{A}}$ \\
\hline Days in Field & $139^{\mathrm{C}}$ & $161^{\mathrm{B}}$ & $161^{\mathrm{B}}$ & $174^{\mathrm{A}}$ & $150^{\mathrm{C}}$ & $178^{\mathrm{A}}$ & $170^{\mathrm{B}}$ & $178^{\mathrm{A}}$ & $145^{\mathrm{B}}$ & $170^{\mathrm{A}}$ & $166^{\mathrm{AB}}$ & $176^{\mathrm{A}}$ \\
\hline Crop Yield (Stalks/ha) & $89,100^{\mathrm{B}}$ & $103,100^{\mathrm{A}}$ & $72,500^{\mathrm{C}}$ & $90,000^{\mathrm{B}}$ & $73,500^{\mathrm{A}}$ & $70,700^{\mathrm{B}}$ & $64,000^{\mathrm{C}}$ & $60,000^{\mathrm{D}}$ & $81,300^{\mathrm{A}}$ & $86,900^{\mathrm{A}}$ & $68,250^{\mathrm{A}}$ & $75,000^{\mathrm{A}}$ \\
\hline Crop Yield $(\%)^{* *}$ & $64^{\mathrm{B}}$ & $74^{\mathrm{A}}$ & $52^{C}$ & $64^{\mathrm{B}}$ & $53^{\mathrm{A}}$ & $51^{B}$ & $46^{\mathrm{C}}$ & $43^{\mathrm{CD}}$ & $58^{\mathrm{AB}}$ & $62^{\mathrm{A}}$ & $49^{\mathrm{C}}$ & $54^{\mathrm{B}}$ \\
\hline Biomass (Mg/ha) & $68^{\mathrm{BC}}$ & $84^{\mathrm{A}}$ & $64^{\mathrm{C}}$ & $71^{\mathrm{B}}$ & $43^{\mathrm{B}}$ & $43^{\mathrm{B}}$ & $45^{\mathrm{B}}$ & $48^{\mathrm{A}}$ & $55^{\mathrm{B}}$ & $63^{A}$ & $55^{\mathrm{B}}$ & $60^{\mathrm{AB}}$ \\
\hline $\begin{array}{l}\text { Stalk Weight ( } \mathrm{g} / 10 \\
\text { stalks) }\end{array}$ & $7,599^{\mathrm{B}}$ & $8,128^{\mathrm{B}}$ & $8,798^{\mathrm{B}}$ & $7,933^{\mathrm{B}}$ & $5,800^{\mathrm{C}}$ & $6,176^{\mathrm{C}}$ & $7,029^{\mathrm{B}}$ & $8,046^{\mathrm{A}}$ & $6,699^{\mathrm{B}}$ & $7,152^{\mathrm{B}}$ & $8,012^{\mathrm{A}}$ & $7,990^{\mathrm{A}}$ \\
\hline $\begin{array}{l}\text { Extraction Efficiency } \\
(\%)\end{array}$ & $29.2^{\mathrm{C}}$ & $32.4^{\mathrm{B}}$ & $32.0^{\mathrm{B}}$ & $35.4^{\mathrm{A}}$ & $30.4^{\mathrm{C}}$ & $30.8^{\mathrm{C}}$ & $32.3^{\mathrm{B}}$ & $38.2^{\mathrm{A}}$ & $29.8^{\mathrm{D}}$ & $31.6^{\mathrm{C}}$ & $33.4^{\mathrm{B}}$ & $36.8^{\mathrm{A}}$ \\
\hline Bagasse Moisture (\%) & $64.3^{\mathrm{A}}$ & $60.3^{\mathrm{B}}$ & $62.5^{\mathrm{AB}}$ & $57.0^{\mathrm{C}}$ & $66.8^{\mathrm{A}}$ & $65.0^{\mathrm{B}}$ & $62.2^{\mathrm{C}}$ & $65.3^{\mathrm{B}}$ & $65.6^{\mathrm{A}}$ & $63.0^{\mathrm{B}}$ & $62.3^{\mathrm{B}}$ & $61.7^{\mathrm{B}}$ \\
\hline Juice Yield (L/ha) & $19,830^{\mathrm{C}}$ & $29,081^{\mathrm{A}}$ & $20,942^{\mathrm{C}}$ & $26,435^{\mathrm{B}}$ & $13,209^{\mathrm{C}}$ & $13,626^{\mathrm{C}}$ & $15,917^{\mathrm{B}}$ & $18,091^{\mathrm{A}}$ & $18,359^{\mathrm{C}}$ & $25,646^{\mathrm{A}}$ & $20,007^{\mathrm{B}}$ & $24,495^{\mathrm{A}}$ \\
\hline Juice Brix & $13.73^{\mathrm{A}}$ & $13.59^{\mathrm{A}}$ & $12.91^{\mathrm{B}}$ & $13.93^{\mathrm{A}}$ & $12.51^{\mathrm{A}}$ & $8.67^{\mathrm{D}}$ & $10.98^{\mathrm{B}}$ & $9.92^{\mathrm{C}}$ & $13.01^{\mathrm{A}}$ & $10.98^{\mathrm{C}}$ & $11.91^{\mathrm{B}}$ & $11.59^{\mathrm{B}}$ \\
\hline Juice $p H$ & $5.82^{\mathrm{A}}$ & $5.90^{\mathrm{A}}$ & $6.26^{\mathrm{A}}$ & $6.08^{\mathrm{A}}$ & $5.33^{\mathrm{B}}$ & $5.24^{\mathrm{C}}$ & $5.41^{\mathrm{A}}$ & $5.19^{\mathrm{C}}$ & $5.40^{\mathrm{AB}}$ & $5.33^{\mathrm{B}}$ & $5.53^{\mathrm{A}}$ & $5.32^{\mathrm{B}}$ \\
\hline Juice Purity (\%) & $75.5^{\mathrm{B}}$ & $69.5^{\mathrm{C}}$ & $80.9^{\mathrm{A}}$ & $80.4^{\mathrm{AB}}$ & $51.7^{\mathrm{C}}$ & $77.7^{\mathrm{A}}$ & $62.7^{\mathrm{B}}$ & $69.5^{\mathrm{B}}$ & $63.4^{\mathrm{B}}$ & $72.7^{\mathrm{AB}}$ & $72.5^{\mathrm{AB}}$ & $75.9^{\mathrm{A}}$ \\
\hline Juice Turbidity (NTU) & $4,100^{\mathrm{A}}$ & $3,691^{\mathrm{B}}$ & $3,857^{\mathrm{AB}}$ & $2,094^{\mathrm{C}}$ & $5,678^{\mathrm{A}}$ & $2,491^{\mathrm{B}}$ & $2,420^{\mathrm{B}}$ & $2,766^{\mathrm{B}}$ & $4,889^{\mathrm{A}}$ & $3,091^{\mathrm{B}}$ & $3,138^{\mathrm{B}}$ & $2,430^{\mathrm{C}}$ \\
\hline Height $(\mathrm{cm})$ & $339^{\mathrm{B}}$ & $370^{\mathrm{A}}$ & $372^{\mathrm{A}}$ & $341^{\mathrm{B}}$ & $313^{\mathrm{C}}$ & $328^{\mathrm{B}}$ & $368^{\mathrm{A}}$ & $311^{\mathrm{C}}$ & $325^{\mathrm{C}}$ & $351^{\mathrm{B}}$ & $371^{\mathrm{A}}$ & $325^{\mathrm{C}}$ \\
\hline $\begin{array}{l}\text { 3rd Node Diameter } \\
(\mathrm{cm})\end{array}$ & $1.96^{\mathrm{B}}$ & $2.06^{\mathrm{A}}$ & $2.00^{\mathrm{B}}$ & $1.98^{\mathrm{B}}$ & $1.76^{\mathrm{C}}$ & $1.86^{\mathrm{B}}$ & $1.86^{\mathrm{B}}$ & $2.08^{\mathrm{A}}$ & $1.86^{\mathrm{C}}$ & $1.96^{\mathrm{B}}$ & $1.94^{\mathrm{B}}$ & $2.03^{\mathrm{A}}$ \\
\hline $\begin{array}{l}\text { 7th Node Diameter } \\
(\mathrm{cm})\end{array}$ & $1.65^{\mathrm{C}}$ & $1.81^{\mathrm{A}}$ & $1.76^{\mathrm{B}}$ & $1.67^{\mathrm{C}}$ & $1.38^{\mathrm{C}}$ & $1.54^{\mathrm{B}}$ & $1.53^{\mathrm{B}}$ & $1.83^{\mathrm{A}}$ & $1.52^{\mathrm{C}}$ & $1.68^{\mathrm{B}}$ & $1.65^{\mathrm{B}}$ & $1.75^{\mathrm{A}}$ \\
\hline $\begin{array}{l}\text { 12th Node Diameter } \\
(\mathrm{cm})\end{array}$ & $1.14^{\mathrm{D}}$ & $1.29^{\mathrm{B}}$ & $1.35^{\mathrm{A}}$ & $1.20^{\mathrm{C}}$ & $0.94^{\mathrm{C}}$ & $1.21^{\mathrm{B}}$ & $1.23^{\mathrm{B}}$ & $1.43^{\mathrm{A}}$ & $1.04^{\mathrm{C}}$ & $1.25^{\mathrm{B}}$ & $1.29^{\mathrm{A}}$ & $1.32^{\mathrm{A}}$ \\
\hline $\begin{array}{l}\text { Average Diameter } \\
(\mathrm{cm})\end{array}$ & $1.58^{\mathrm{B}}$ & $1.72^{\mathrm{A}}$ & $1.70^{\mathrm{A}}$ & $1.62^{\mathrm{B}}$ & $1.36^{\mathrm{C}}$ & $1.54^{\mathrm{B}}$ & $1.54^{\mathrm{B}}$ & $1.78^{\mathrm{A}}$ & $1.47^{\mathrm{C}}$ & $1.63^{\mathrm{B}}$ & $1.62^{\mathrm{B}}$ & $1.70^{\mathrm{A}}$ \\
\hline $\begin{array}{l}\text { Average Temperature } \\
\left({ }^{\circ} \mathrm{C}\right)\end{array}$ & $2.66^{\mathrm{AB}}$ & $2.66^{\mathrm{A}}$ & $2.66^{\mathrm{A}}$ & $2.65^{\mathrm{B}}$ & $2.59^{\mathrm{A}}$ & $2.58^{\mathrm{A}}$ & $2.59^{\mathrm{A}}$ & $2.58^{\mathrm{A}}$ & $2.62^{\mathrm{A}}$ & $2.62^{\mathrm{A}}$ & $2.63^{\mathrm{A}}$ & $2.62^{\mathrm{A}}$ \\
\hline Average Rainfall $(\mathrm{cm})$ & $24.7^{\mathrm{C}}$ & $26.0^{\mathrm{B}}$ & $26.0^{\mathrm{B}}$ & $27.4^{\mathrm{C}}$ & $17.8^{\mathrm{B}}$ & $19.2^{\mathrm{B}}$ & $23.3^{\mathrm{A}}$ & $22.0^{\mathrm{A}}$ & $21.5^{\mathrm{B}}$ & $22.6^{\mathrm{B}}$ & $24.7^{\mathrm{A}}$ & $24.7^{\mathrm{A}}$ \\
\hline
\end{tabular}

"Mean results followed by the same upper case letter within rows are compared within year or two-year average and are not significantly different at the $5 \%$ probability level. ${ }^{* *}$ Crop yield $(\%)$ was calculated by dividing the number of stalks per hectare by 140,000 . 
Table A2. Agronomic, crop performance, physical, juice quality attributes of sweet sorghum by maturity during 2013 and 2014 seasons.

\begin{tabular}{|c|c|c|c|c|c|c|c|c|c|c|c|c|c|c|c|}
\hline & \multicolumn{5}{|c|}{2013} & \multicolumn{5}{|c|}{2014} & \multicolumn{5}{|c|}{ Two-Year Average } \\
\hline$\underline{\text { Parameter }}$ & Mi & SD & HD & PM & PPM & Mi & SD & HD & PM & PPM & Mi & SD & HD & PM & PPM \\
\hline Days to Milk & \multicolumn{5}{|c|}{ n.a. } & \multicolumn{5}{|c|}{ n.a. } & \multicolumn{5}{|c|}{ n.a. } \\
\hline Days in Field & $96^{\mathrm{D}}$ & $110^{\mathrm{C}}$ & $123^{\mathrm{BC}}$ & $139^{\mathrm{A}}$ & $157^{\mathrm{A}}$ & $115^{\mathrm{D}}$ & $127^{\mathrm{C}}$ & $141^{\mathrm{BC}}$ & $155^{\mathrm{AB}}$ & $169^{\mathrm{A}}$ & $105^{\mathrm{D}}$ & $119^{\mathrm{C}}$ & $132^{\mathrm{BC}}$ & $147^{\mathrm{B}}$ & $163^{\mathrm{A}}$ \\
\hline${ }^{+}$Crop Yield (Stalks/ha) & \multicolumn{5}{|c|}{$88,675^{\mathrm{A}}$} & \multicolumn{5}{|c|}{$67,026^{\mathrm{B}}$} & \multicolumn{5}{|c|}{$77,851^{*}$} \\
\hline${ }^{+}$Crop Yield $(\%)$ & \multicolumn{5}{|c|}{$63^{\mathrm{A}}$} & \multicolumn{5}{|c|}{$48^{\mathrm{B}}$} & \multicolumn{5}{|c|}{$56^{\ddagger}$} \\
\hline Biomass $(M g / h a)$ & $84^{\mathrm{A}}$ & $76^{\mathrm{B}}$ & $70^{\mathrm{BC}}$ & $68^{\mathrm{CD}}$ & $61^{\mathrm{D}}$ & $44^{\mathrm{B}}$ & $47^{\mathrm{A}}$ & $47^{\mathrm{A}}$ & $39^{\mathrm{C}}$ & $46^{\mathrm{AB}}$ & $64^{\mathrm{A}}$ & $62^{\mathrm{AB}}$ & $59^{\mathrm{ABC}}$ & $54^{\mathrm{C}}$ & $55^{\mathrm{C}}$ \\
\hline Stalk Weight (kg/10 stalks) & $9.51^{\mathrm{A}}$ & $8.61^{\mathrm{B}}$ & $7.91^{\mathrm{C}}$ & $7.60^{\mathrm{C}}$ & $6.95^{\mathrm{D}}$ & $6.69^{\mathrm{A}}$ & $7.16^{\mathrm{A}}$ & $7.14^{\mathrm{A}}$ & $5.98^{\mathrm{B}}$ & $6.78^{\mathrm{A}}$ & $8.10^{\mathrm{A}}$ & $7.89^{\mathrm{B}}$ & $7.52^{\mathrm{BC}}$ & $6.79^{\mathrm{C}}$ & $6.88^{\mathrm{C}}$ \\
\hline Extraction Efficiency (\%) & $30.0^{\mathrm{B}}$ & $35.3^{\mathrm{A}}$ & $34.3^{\mathrm{A}}$ & $31.2^{\mathrm{B}}$ & $30.5^{\mathrm{B}}$ & $31.3^{\mathrm{B}}$ & $33.0^{\mathrm{AB}}$ & $35.5^{\mathrm{A}}$ & $33.5^{\mathrm{AB}}$ & $35.0^{\mathrm{A}}$ & $30.6^{\mathrm{A}}$ & $34.1^{\mathrm{AB}}$ & $34.9^{\mathrm{A}}$ & $32.4^{\mathrm{BC}}$ & $32.4^{\mathrm{BC}}$ \\
\hline Bagasse Moisture (\%) & $64.5^{\mathrm{A}}$ & $62.6^{\mathrm{A}}$ & $58.7^{\mathrm{B}}$ & $54.2^{\mathrm{C}}$ & $64.3^{\mathrm{A}}$ & $61.4^{\mathrm{C}}$ & $67.0^{\mathrm{A}}$ & $63.7^{\mathrm{B}}$ & $66.9^{\mathrm{A}}$ & $66.0^{\mathrm{A}}$ & $62.9^{\mathrm{B}}$ & $64.8^{\mathrm{A}}$ & $61.4^{\mathrm{C}}$ & $62.1^{\mathrm{BC}}$ & $65.3^{A}$ \\
\hline Juice Yield (L/ha) & $25,752^{\mathrm{B}}$ & $27,994^{\mathrm{A}}$ & $25,191^{\mathrm{B}}$ & $21,557^{\mathrm{C}}$ & $19,360^{\mathrm{D}}$ & $13,587^{\mathrm{B}}$ & $15,843^{\mathrm{A}}$ & $17,222^{\mathrm{A}}$ & $13,367^{\mathrm{B}}$ & $16,078^{\mathrm{A}}$ & $23,048^{\mathrm{B}}$ & $25,294^{\mathrm{A}}$ & $23,420^{\mathrm{B}}$ & $19,737^{\mathrm{C}}$ & $18,745^{c}$ \\
\hline Juice Brix & $11.36^{\mathrm{D}}$ & $13.33^{\mathrm{C}}$ & $14.38^{\mathrm{AB}}$ & $14.75^{\mathrm{A}}$ & $14.03^{\mathrm{B}}$ & $11.21^{\mathrm{A}}$ & $10.46^{\mathrm{B}}$ & $10.55^{\mathrm{B}}$ & $10.61^{\mathrm{B}}$ & $9.91^{\mathrm{C}}$ & $11.23^{\mathrm{D}}$ & $11.78^{\mathrm{C}}$ & $12.19^{\mathrm{AB}}$ & $12.30^{\mathrm{A}}$ & $11.95^{\mathrm{BC}}$ \\
\hline Juice $\mathrm{pH}$ & $5.62^{\mathrm{B}}$ & $5.84^{\mathrm{AB}}$ & $6.27^{\mathrm{A}}$ & $6.14^{\mathrm{A}}$ & $6.19^{\mathrm{A}}$ & $5.31^{\mathrm{AB}}$ & $5.35^{\mathrm{A}}$ & $5.31^{\mathrm{AB}}$ & $5.22^{\mathrm{C}}$ & $5.26^{\mathrm{BC}}$ & $5.36^{\mathrm{A}}$ & $5.42^{\mathrm{A}}$ & $5.45^{\mathrm{A}}$ & $5.35^{\mathrm{A}}$ & $5.36^{\mathrm{A}}$ \\
\hline Juice Purity (\%) & $80.6^{\mathrm{A}}$ & $72.1^{\mathrm{C}}$ & $80.1^{\mathrm{A}}$ & $64.8^{\mathrm{D}}$ & $76.6^{\mathrm{B}}$ & $63.0^{\mathrm{B}}$ & $52.4^{\mathrm{C}}$ & $58.3^{\mathrm{BC}}$ & $57.9^{\mathrm{BC}}$ & $72.1^{\mathrm{A}}$ & $71.8^{\mathrm{A}}$ & $62.3^{C}$ & $69.2^{\mathrm{AB}}$ & $61.3^{\mathrm{BC}}$ & $74.4^{\mathrm{A}}$ \\
\hline Juice Turbidity (NTU) & $4,480^{\mathrm{A}}$ & $3,071^{\mathrm{C}}$ & $2,694^{\mathrm{D}}$ & $3,888^{\mathrm{B}}$ & $3,011^{\mathrm{C}}$ & $2,540^{\mathrm{D}}$ & $3,747^{\mathrm{B}}$ & $3,065^{\mathrm{C}}$ & $4,437^{\mathrm{A}}$ & $2,907^{\mathrm{C}}$ & $3,833^{\mathrm{B}}$ & $3,296^{\mathrm{C}}$ & $2,818^{\mathrm{D}}$ & $4,071^{\mathrm{A}}$ & $2,976^{\mathrm{CD}}$ \\
\hline Height $(\mathrm{cm})$ & $337^{\mathrm{C}}$ & $364^{\mathrm{A}}$ & $366^{\mathrm{A}}$ & $357^{\mathrm{B}}$ & $354^{\mathrm{B}}$ & $334^{\mathrm{A}}$ & $323^{\mathrm{B}}$ & $336^{\mathrm{A}}$ & $324^{\mathrm{B}}$ & $324^{\mathrm{B}}$ & $335^{\mathrm{C}}$ & $343^{A}$ & $351^{\mathrm{A}}$ & $340^{\mathrm{B}}$ & $340^{\mathrm{B}}$ \\
\hline $3 r d$ Node Diameter $(\mathrm{cm})$ & $2.14^{\mathrm{A}}$ & $2.03^{\mathrm{B}}$ & $2.03^{\mathrm{B}}$ & $1.91^{\mathrm{C}}$ & $1.90^{\mathrm{C}}$ & $1.77^{\mathrm{D}}$ & $1.87^{\mathrm{C}}$ & $1.94^{\mathrm{AB}}$ & $1.92^{\mathrm{BC}}$ & $1.98^{\mathrm{A}}$ & $1.96^{\mathrm{A}}$ & $1.95^{\mathrm{ABC}}$ & $1.99^{\mathrm{A}}$ & $1.91^{\mathrm{C}}$ & $1.93^{\mathrm{BC}}$ \\
\hline 7th Node Diameter (cm) & $1.83^{\mathrm{A}}$ & $1.76^{\mathrm{B}}$ & $1.76^{\mathrm{B}}$ & $1.61^{\mathrm{C}}$ & $1.64^{\mathrm{C}}$ & $1.49^{\mathrm{C}}$ & $1.60^{\mathrm{A}}$ & $1.60^{\mathrm{AB}}$ & $1.54^{\mathrm{BC}}$ & $1.65^{\mathrm{A}}$ & $1.66^{\mathrm{A}}$ & $1.68^{\mathrm{A}}$ & $1.68^{\mathrm{A}}$ & $1.57^{\mathrm{B}}$ & $1.64^{\mathrm{A}}$ \\
\hline 12th Node Diameter $(\mathrm{cm})$ & $1.83^{\mathrm{A}}$ & $1.32^{\mathrm{B}}$ & $1.20^{\mathrm{C}}$ & $1.15^{\mathrm{CD}}$ & $1.13^{\mathrm{D}}$ & $1.12^{\mathrm{D}}$ & $1.28^{\mathrm{A}}$ & $1.25^{\mathrm{AB}}$ & $1.16^{\mathrm{CD}}$ & $1.20^{\mathrm{BC}}$ & $1.27^{\mathrm{A}}$ & $1.30^{\mathrm{A}}$ & $1.23^{\mathrm{B}}$ & $1.15^{\mathrm{C}}$ & $1.16^{\mathrm{C}}$ \\
\hline Average Diameter $(\mathrm{cm})$ & $1.42^{\mathrm{A}}$ & $1.72^{\mathrm{A}}$ & $1.68^{\mathrm{A}}$ & $1.55^{\mathrm{A}}$ & $1.59^{\mathrm{A}}$ & $1.45^{\mathrm{A}}$ & $1.60^{\mathrm{A}}$ & $1.59^{\mathrm{A}}$ & $1.52^{\mathrm{A}}$ & $1.61^{\mathrm{A}}$ & $1.63^{\mathrm{A}}$ & $1.64^{\mathrm{A}}$ & $1.63^{\mathrm{A}}$ & $1.54^{\mathrm{B}}$ & $1.58^{\mathrm{AB}}$ \\
\hline Average Temperature $\left({ }^{\circ} \mathrm{C}\right)$ & $26.5^{\mathrm{B}}$ & $26.6^{\mathrm{A}}$ & $26.7^{\mathrm{A}}$ & $26.6^{\mathrm{A}}$ & $26.3^{\mathrm{C}}$ & $25.8^{\mathrm{B}}$ & $26.0^{\mathrm{A}}$ & $26.1^{\mathrm{A}}$ & $25.8^{\mathrm{B}}$ & $25.6^{\mathrm{C}}$ & $26.2^{\mathrm{B}}$ & $26.3^{\mathrm{AB}}$ & $26.4^{\mathrm{A}}$ & $26.3^{\mathrm{AB}}$ & $25.9^{\mathrm{C}}$ \\
\hline Average Rainfall $(\mathrm{cm})$ & $24.0^{\mathrm{E}}$ & $25.3^{\mathrm{D}}$ & $26.1^{\mathrm{C}}$ & $26.7^{\mathrm{B}}$ & $28.2^{\mathrm{A}}$ & $16.2^{\mathrm{D}}$ & $18.1^{\mathrm{C}}$ & $19.5^{\mathrm{C}}$ & $23.3^{\mathrm{B}}$ & $25.8^{\mathrm{A}}$ & $20.4^{\mathrm{D}}$ & $21.7^{\mathrm{CD}}$ & $22.8^{\mathrm{C}}$ & $25.0^{\mathrm{B}}$ & $27.0^{\mathrm{A}}$ \\
\hline
\end{tabular}

"Mean results followed by the same upper case letter within rows are compared within year and are not significantly different at the 5\% probability level. ${ }^{+}$Mean results followed by the same upper case letter within rows are compared between year and are not significantly different at the 5\% probability level. ${ }^{+}$n.a.=not applicable 
Table A3. Pearson correlation coefficients (R) for two year average weather, agronomy, and juice quality attributes for the four cultivars at five physiological maturities. Results are significant at the 5\% probability level. Weak correlations values $<0.300$ are not listed.

\begin{tabular}{|c|c|c|c|c|c|c|c|c|c|c|c|}
\hline Parameters & DTM & Temp. & Rain & $\begin{array}{c}\text { Wet } \\
\text { Biomass }\end{array}$ & Yield & $\begin{array}{c}\text { Wet Stalk } \\
\text { Wt. }\end{array}$ & Moisture & Height & $\begin{array}{l}\text { Avg. } \\
\text { Diam. }\end{array}$ & $\begin{array}{l}\text { Extr. } \\
\text { Effic. }\end{array}$ & $\begin{array}{l}\text { Juice } \\
\text { Yield }\end{array}$ \\
\hline DTM $^{*}$ & 1.000 & & & & & & & & & & \\
\hline Temp. ${ }^{*}$ & & 1.000 & & & & & & & & & \\
\hline Rain & 0.666 & 0.417 & 1.000 & & & & & & & & \\
\hline Wet Biomass & -0.505 & 0.887 & & 1.000 & & & & & & & \\
\hline Yield & -0.595 & 0.608 & & 0.883 & 1.000 & & & & & & \\
\hline $\begin{array}{c}\text { Wet Stalk } \\
\text { Wt. }\end{array}$ & & 0.881 & 0.427 & 0.695 & & 1.000 & & & & & \\
\hline Moisture & 0.040 & -0.844 & -0.517 & -0.759 & -0.574 & -0.656 & 1.000 & & & & \\
\hline Height & & 0.637 & & 0.557 & 0.358 & 0.545 & -0.722 & 1.000 & & & \\
\hline Avg. Diam. ${ }^{*}$ & 0.170 & 0.709 & 0.592 & 0.528 & & 0.896 & -0.476 & 0.301 & 1.000 & & \\
\hline Extr. Effic.* & 0.697 & & 0.646 & & -0.369 & 0.392 & -0.336 & & 0.540 & 1.000 & \\
\hline Juice Yield & & 0.898 & & 0.947 & 0.768 & 0.768 & -0.856 & 0.521 & 0.641 & & 1.000 \\
\hline Brix & -0.799 & 0.588 & -0.361 & 0.740 & 0.749 & 0.398 & -0.521 & 0.389 & & & 0.661 \\
\hline Gluc.* & 0.502 & & 0.391 & -0.607 & -0.788 & & 0.400 & -0.431 & & & -0.527 \\
\hline Fruc. ${ }^{*}$ & -0.332 & 0.508 & & & & 0.489 & & & 0.306 & & \\
\hline Suc. ${ }^{*}$ & -0.542 & 0.813 & & 0.946 & 0.917 & 0.534 & -0.808 & 0.567 & & & 0.899 \\
\hline Total Sug ${ }^{*}$ & -0.497 & 0.897 & & 0.828 & 0.668 & 0.688 & -0.708 & 0.436 & 0.428 & & 0.779 \\
\hline Juice Purity & & 0.740 & 0.637 & 0.478 & & 0.590 & -0.509 & 0.302 & 0.578 & & 0.457 \\
\hline Total Starch & -0.770 & 0.314 & -0.577 & 0.674 & 0.812 & & & 0.342 & & -0.527 & 0.507 \\
\hline Starch Size & & & -0.321 & 0.897 & 0.922 & & & & & & 0.590 \\
\hline Turb. & -0.727 & -0.322 & -0.980 & & & & 0.512 & & -0.450 & -0.656 & \\
\hline $\mathrm{TOC}^{*}$ & -0.707 & 0.577 & -0.392 & 0.722 & 0.730 & 0.386 & -0.552 & 0.421 & & & 0.676 \\
\hline TON $^{*}$ & -0.466 & & -0.355 & & & 0.453 & & 0.343 & & & \\
\hline $\mathrm{N}^{*}$ & -0.601 & 0.671 & & 0.535 & 0.400 & 0.491 & -0.524 & 0.549 & & & 0.427 \\
\hline Cond. Ash ${ }^{*}$ & & 0.682 & 0.541 & 0.708 & 0.503 & 0.673 & -0.558 & & 0.833 & 0.378 & 0.784 \\
\hline $\mathrm{P}^{*}$ & -0.325 & -0.409 & -0.510 & 0.002 & 0.325 & -0.469 & 0.279 & -0.367 & -0.438 & -0.210 & -0.061 \\
\hline $\mathrm{pH}$ & -0.558 & 0.867 & 0.038 & 0.788 & 0.613 & 0.678 & -0.724 & 0.654 & 0.339 & & 0.729 \\
\hline
\end{tabular}

* parameter abbreviations: days to milk (DTM), temperature (Temp.), crop yield (Yield), stalk weight (St. Wt.), average stalk diameter (Avg. Diam.), extraction efficiency (Extr. Effic.), glucose (Gluc.), fructose (Fruc.), sucrose (Suc.), total sugars (Total Sug.), turbidity (turb.), total organic carbon (TOC), total organic nitrogen (TON), assimilable nitrogen $(\mathrm{N})$, conductivity ash (Cond. Ash), and phosphate $(\mathrm{P}) .{ }^{\dagger}$ In raw juices 
Table A3 (continued). Pearson correlation coefficients (R) for two year average weather, agronomy, and juice quality attributes for the four cultivars at five physiological maturities. Results are significant at the $5 \%$ probability level. Weak correlations values $<0.300$ are not listed.

\begin{tabular}{|c|c|c|c|c|c|c|c|c|c|c|c|c|c|c|c|}
\hline Parameters & Brix & Gluc. & Fruc. & Suc. & $\begin{array}{l}\text { Total } \\
\text { Sug. }\end{array}$ & $\begin{array}{l}\text { Juice } \\
\text { Purity }\end{array}$ & $\begin{array}{c}\text { Total } \\
\text { Starch }\end{array}$ & $\begin{array}{c}\text { Starch } \\
\text { Size }\end{array}$ & Turb. & TOC & TON & $\mathrm{N}$ & $\begin{array}{l}\text { Elec. } \\
\text { Cond. }\end{array}$ & $\mathrm{P}$ & $\mathrm{pH}$ \\
\hline Brix & 1.000 & & & & & & & & & & & & & & \\
\hline Gluc.* & -0.584 & 1.000 & & & & & & & & & & & & & \\
\hline Fruc. ${ }^{*}$ & 0.333 & 0.482 & 1.000 & & & & & & & & & & & & \\
\hline Suc. ${ }^{*}$ & 0.850 & -0.684 & & 1.000 & & & & & & & & & & & \\
\hline Total Sug ${ }^{*}$ & 0.767 & & 0.694 & 0.837 & 1.000 & & & & & & & & & & \\
\hline Juice Purity & & & 0.694 & 0.377 & 0.696 & 1.000 & & & & & & & & & \\
\hline Total Starch & 0.688 & -0.893 & & 0.679 & 0.334 & & 1.000 & & & & & & & & \\
\hline Starch Size & 0.430 & -0.899 & -0.841 & 0.672 & -0.645 & -0.982 & 0.904 & 1.000 & & & & & & & \\
\hline Turb. & 0.374 & -0.366 & & & & -0.555 & 0.616 & & 1.000 & & & & & & \\
\hline TOC $^{*}$ & 0.955 & -0.658 & & 0.845 & 0.697 & 0.059 & 0.724 & & 0.392 & 1.000 & & & & & \\
\hline $\mathrm{TON}^{*}$ & & & 0.379 & & & & & -0.400 & 0.480 & & 1.000 & & & & \\
\hline $\mathrm{N}^{*}$ & 0.715 & & 0.759 & 0.615 & 0.845 & 0.533 & & -0.831 & & 0.607 & 0.367 & 1.000 & & & \\
\hline Cond. Ash ${ }^{*}$ & & & & 0.509 & 0.449 & 0.513 & & 0.858 & -0.452 & & & & 1.000 & & \\
\hline $\mathrm{P}^{*}$ & 0.225 & -0.490 & -0.510 & 0.072 & -0.250 & -0.687 & 0.431 & 0.842 & 0.442 & 0.118 & -0.288 & -0.311 & -0.068 & 1.000 & \\
\hline $\mathrm{pH}$ & 0.794 & -0.330 & 0.586 & 0.829 & 0.909 & 0.576 & 0.451 & 0.368 & -0.809 & & 0.811 & 0.345 & 0.857 & & -0.385 \\
\hline
\end{tabular}

parameter abbreviations: days to milk (DTM), temperature (Temp.), crop yield (Yield), stalk weight (St. Wt.), average stalk diameter (Avg. Diam.), extraction efficiency (Extr. Effic.), glucose (Gluc.), fructose (Fruc.), sucrose (Suc.), total sugars (Total Sug.), turbidity (turb.), total organic carbon (TOC), total organic nitrogen (TON), assimilable nitrogen $(\mathrm{N})$, conductivity ash (Cond. Ash and phosphate (P). ${ }^{\dagger}$ In raw juices 
Table A4. Conductivity ash (mS/cm), total organic carbon (TOC, ppm), total organic nitrogen (TON, ppm), assimilable nitrogen (YAN, ppm), and phosphate (ppm) in extracted sweet sorghum juice. Same letters across columns are not statistically different at the 5\% probability level.

\begin{tabular}{|c|c|c|c|c|c|c|c|c|c|}
\hline & \multicolumn{4}{|c|}{ Cultivar } & \multicolumn{5}{|c|}{ Maturity } \\
\hline & Dale & $M 81 E$ & Theis & Top 76-6 & $M i$ & $S D$ & $H D$ & $P M$ & $P P M$ \\
\hline \multicolumn{10}{|c|}{ Conductivity Ash (mS/cm) } \\
\hline 2013 & $6.1^{\mathrm{BC}}$ & $7.4^{\mathrm{A}}$ & $5.8^{\mathrm{C}}$ & $6.5^{\mathrm{B}}$ & $7.6^{\mathrm{A}}$ & $6.2^{\mathrm{BC}}$ & $6.3^{\mathrm{BC}}$ & $5.7^{\mathrm{C}}$ & $6.6^{\mathrm{B}}$ \\
\hline 2014 & 4.7 & $6.0^{\mathrm{B}}$ & $5.4^{\mathrm{B}}$ & $6.8^{\mathrm{A}}$ & $5.1^{\mathrm{C}}$ & $6.7^{\mathrm{A}}$ & $5.5^{\mathrm{BC}}$ & $6.1^{\mathrm{AB}}$ & $5.4^{\mathrm{BC}}$ \\
\hline$\%$ Change & $-24.1 \%$ & $-19.4 \%$ & $-5.9 \%$ & $4.3 \%$ & $-33.3 \%$ & $7.6 \%$ & $-12.8 \%$ & $6.1 \%$ & $-18.5 \%$ \\
\hline Two Year Avg & $5.4^{\mathrm{B}}$ & $6.7^{\mathrm{A}}$ & $5.6^{\mathrm{B}}$ & $6.7^{\mathrm{A}}$ & $6.3^{\mathrm{A}}$ & $6.4^{\mathrm{A}}$ & $5.9^{\mathrm{A}}$ & $5.9^{\mathrm{A}}$ & $6.0^{\mathrm{A}}$ \\
\hline \multicolumn{10}{|c|}{ TOC (ppm) } \\
\hline 2013 & $56,959^{\mathrm{B}}$ & $65,407^{\mathrm{A}}$ & $62,213^{\mathrm{AB}}$ & $65,690^{\mathrm{A}}$ & $52,798^{\mathrm{B}}$ & $64,529^{A}$ & $63,372^{A}$ & $64,108^{A}$ & $68,030^{A}$ \\
\hline 2014 & $59,554^{\mathrm{A}}$ & $38,005^{\mathrm{C}}$ & $47,539^{\mathrm{B}}$ & $42,436^{\mathrm{BC}}$ & $51,008^{\mathrm{A}}$ & $46,336^{\mathrm{A}}$ & $46,077^{\mathrm{A}}$ & $46,638^{\mathrm{A}}$ & $44,358^{\mathrm{A}}$ \\
\hline$\%$ Change & $4.6 \%$ & $-41.9 \%$ & $-23.6 \%$ & $-35.4 \%$ & $-3.4 \%$ & $-28.2 \%$ & $-27.3 \%$ & $-27.3 \%$ & $-34.8 \%$ \\
\hline Two Year Avg & $58,256^{\mathrm{A}}$ & $51,706^{\mathrm{A}}$ & $54,876^{\mathrm{A}}$ & $54,063^{\mathrm{A}}$ & $51,903^{\mathrm{A}}$ & $55,432^{\mathrm{A}}$ & $54,725^{\mathrm{A}}$ & $55,373^{\mathrm{A}}$ & $56,194^{\mathrm{A}}$ \\
\hline \multicolumn{10}{|c|}{ TON $(p p m)$} \\
\hline 2013 & $197.2^{\mathrm{B}}$ & $179.6^{\mathrm{BC}}$ & $263.6^{\mathrm{A}}$ & $137.8^{\mathrm{C}}$ & $232.0^{\mathrm{A}}$ & $275.3^{\mathrm{A}}$ & $177.0^{\mathrm{B}}$ & $143.8^{\mathrm{B}}$ & $144.5^{\mathrm{B}}$ \\
\hline 2014 & $195.4^{\mathrm{A}}$ & $127.6^{\mathrm{B}}$ & $191.8^{\mathrm{A}}$ & $196.8^{\mathrm{A}}$ & $150.3^{\mathrm{B}}$ & $191.8^{\mathrm{A}}$ & $181.3^{\mathrm{AB}}$ & $192.0^{\mathrm{A}}$ & $174.3^{\mathrm{AB}}$ \\
\hline$\%$ Change & $-0.9 \%$ & $-29.0 \%$ & $-27.2 \%$ & $42.8 \%$ & $-35.2 \%$ & $-30.3 \%$ & $2.4 \%$ & $33.6 \%$ & $20.6 \%$ \\
\hline Two Year Avg & $196.3^{\mathrm{B}}$ & $153.6^{\mathrm{C}}$ & $227.7^{\mathrm{A}}$ & $167.3^{\mathrm{BC}}$ & $191.1^{\mathrm{B}}$ & $233.6^{\mathrm{A}}$ & $179.1^{\mathrm{B}}$ & $167.9^{\mathrm{B}}$ & $150.4^{\mathrm{B}}$ \\
\hline \multicolumn{10}{|c|}{ YAN (ppm) } \\
\hline 2013 & $98.9^{\mathrm{A}}$ & $53.7^{\mathrm{B}}$ & $99.4^{\mathrm{A}}$ & $88.7^{\mathrm{A}}$ & $55.5^{\mathrm{B}}$ & $109.5^{\mathrm{A}}$ & $84.0^{\mathrm{B}}$ & $94.2^{\mathrm{AB}}$ & $82.7^{\mathrm{B}}$ \\
\hline 2014 & $41.1^{\mathrm{B}}$ & $35.7^{\mathrm{B}}$ & $63.3^{\mathrm{A}}$ & $28.9^{\mathrm{C}}$ & $51.9^{\mathrm{A}}$ & $51.9^{\mathrm{A}}$ & $43.8^{\mathrm{B}}$ & $34.6^{\mathrm{C}}$ & $29.1^{\mathrm{C}}$ \\
\hline$\%$ Change & $-58.4 \%$ & $-33.5 \%$ & $-36.3 \%$ & $-67.4 \%$ & $-6.5 \%$ & $-52.6 \%$ & $-47.9 \%$ & $-63.3 \%$ & $-64.8 \%$ \\
\hline Two Year Avg & $62.8^{\mathrm{B}}$ & $42.4^{\mathrm{C}}$ & $76.9^{\mathrm{A}}$ & $51.4^{\mathrm{C}}$ & $53.2^{\mathrm{B}}$ & $73.5^{\mathrm{A}}$ & $58.9^{\mathrm{B}}$ & $56.9^{\mathrm{B}}$ & $49.2^{\mathrm{B}}$ \\
\hline \multicolumn{10}{|c|}{ Phosphate (ppm) } \\
\hline 2013 & $78.5^{\mathrm{A}}$ & $77^{\mathrm{A}}$ & $44.2^{\mathrm{B}}$ & $64.8^{\mathrm{A}}$ & $46.4^{\mathrm{B}}$ & $65.1^{\mathrm{A}}$ & $71^{\mathrm{A}}$ & $71.7^{\mathrm{A}}$ & $76.3^{A}$ \\
\hline 2014 & $83.8^{\mathrm{A}}$ & $60.4^{\mathrm{B}}$ & $69^{\mathrm{B}}$ & $67.4^{\mathrm{B}}$ & $43.4^{\mathrm{B}}$ & $70.5^{\mathrm{A}}$ & $81.4^{\mathrm{A}}$ & $78.1^{\mathrm{A}}$ & $77.3^{\mathrm{A}}$ \\
\hline$\%$ Change & $6.8 \%$ & $-21.6 \%$ & $56.1 \%$ & $4.0 \%$ & $-6.5 \%$ & $8.3 \%$ & $14.6 \%$ & $8.9 \%$ & $1.3 \%$ \\
\hline Two Year Avg & $81.7^{\mathrm{A}}$ & $67^{\mathrm{B}}$ & $59.1^{\mathrm{B}}$ & $66.3^{\mathrm{B}}$ & $44.6^{\mathrm{B}}$ & $68.4^{\mathrm{A}}$ & $77.2^{\mathrm{A}}$ & $75.6^{\mathrm{A}}$ & $76.9^{\mathrm{A}}$ \\
\hline
\end{tabular}

